\title{
Atom order and thermodynamic properties of the ternary Laves phase $\mathbf{T i}\left(\operatorname{Ti}_{y} \mathbf{N i}_{x} \mathrm{Al}_{1-x-y}\right)_{2}$
}

\author{
Andriy Grytsiv ${ }^{\mathrm{I}}$, Xing-Qiu Chen ${ }^{\mathrm{I}}$, Viktor T. Witusiewicz ${ }^{\mathrm{II}}$, Peter Rog1*,I, Raimund Podloucky, Vladimir Pomjakushin ${ }^{\mathrm{III}}$, \\ Daniele Maccio $^{\mathrm{IV}}$, Adriana Saccone ${ }^{\mathrm{IV}}$, Gerald Giester ${ }^{\mathrm{V}}$ and Ferdinand Sommer ${ }^{\mathrm{VI}}$ \\ I Institut für Physikalische Chemie, Universität Wien, Währingerstraße 42, 1090 Wien, Austria \\ II ACCESS e.V., RWTH Aachen, Intzestraße 5, 52072 Aachen, Germany \\ III Laboratorium für Neutronenstreuung, ETHZ \& PSI, 5232 Villigen, Switzerland \\ IV Dipartimento di Chimica e Chimica Industriale, Sez. di Chimica Inorganica e Metallurgia, Universita' di Genova, Via Dodecaneso 31, \\ 16146 Genova, Italy \\ V Institut für Mineralogie und Kristallographie, Universität Wien, Althanstraße 14, 1090 Wien, Austria

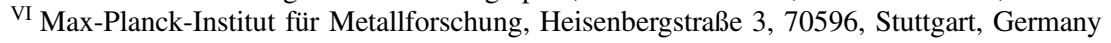

In commemoration of the $100^{\text {th }}$ anniversary of Fritz Laves' birthday

Received July 14, 2005; accepted November 14, 2005

\section{Ternary titanium aluminides / Neutron scattering / Thermodynamics and ab-initio calculation / Single crystal structure analysis / \\ Powder diffraction structure analysis / X-ray diffraction}

\begin{abstract}
Combined refinement of neutron powder, X-ray single crystal and powder diffraction data allows precise evaluation of symmetry and atom site occupation for the $\mathrm{MgZn}_{2}$-type Laves phase. For compositions $\mathrm{Ti}\left(\mathrm{Ni}_{1-x}, \mathrm{Al}_{x}\right)_{2}$ titanium atoms were found to fully occupy the $4 f$ site, whilst Ni- and Al-atoms randomly share the $2 a$ and $6 h$ sub-lattice sites of space group $P 6_{3} / m m c$. At higher Ti-concentrations, Ti-atoms tend to enter the $2 a$ and $6 h$ site. Compositional dependences of the site occupations were used to explain the curved shape of the homogeneity region of the Laves phase. Investigation of the phase relations around the Ti-rich side of the ternary Laves phase was based on LOM, EPMA and X-ray diffraction experiments on argon arc-melted bulk alloys, which were annealed at $1000{ }^{\circ} \mathrm{C}$ in vacuum-sealed silica capsules for $100 \mathrm{~h}$. The Tirich end of the homogeneity region of the ternary Laves phase at $1000{ }^{\circ} \mathrm{C}$ was derived from EMPA to be at $\mathrm{Ti}_{0.463} \mathrm{Ni}_{0.273} \mathrm{Al}_{0.264}$. Heat of formation data, derived from adiabatic drop calorimetry, were $\Delta_{298} H^{0}=-57.9 \pm 3.5 \mathrm{~kJ} /$ mol for $\mathrm{Ti}_{0.34} \mathrm{Ni}_{0.18} \mathrm{Al}_{0.48}$ and $-61.6 \pm 3.3 \mathrm{~kJ} / \mathrm{mol}$ for $\mathrm{Ti}_{0.36} \mathrm{Ni}_{0.24} \mathrm{Al}_{0.40}$. For the ab initio density functional theory applications a large number of structural models were investigated in order to calculate the concentration dependent heats of formation, structural stabilities, lattice parameters, bulk moduli and site occupancies, which are in good agreement with experiment. The theoretical analysis revealed that there are no $\mathrm{Ni}-\mathrm{Ni}$ nearest neighbours when the concentra-
\end{abstract}

* Correspondence author (e-mail: peter.franz.rogl@univie.ac.at) tion of $\mathrm{Ni}$ is smaller than that of $\mathrm{Al}$. With increasing $\mathrm{Al}$ concentration, $\mathrm{Al}$ starts to fill $2 a$ sites, and then continues occupying $6 h$ sites. In compounds with Ti concentration larger than 33.3 at $\%$ the $4 f$ sites are fully occupied by $\mathrm{Ti}$, and the excessive Ti prefers $6 h$ sites. The Al concentration of the Al-rich end of the homogeneity region of the ternary Laves phase was predicted to be 57 at $\%$.

\section{Introduction}

Titanium aluminides alloyed with nickel are light-weight materials with high specific strength and stiffness envisaged to be used as important engineering materials for static structural components and/or for turbine blades in the low-pressure turbine section of aero-engines. Desired improvements concern the increase in service temperature, the increase of strength at elevated temperature, the increase of room temperature ductility and toughness as well as a thermo-mechanical processing technology (forging and extrusion) as for Ni-base superalloys.

Phase equilibria in the ternary system $\mathrm{Ti}-\mathrm{Ni}-\mathrm{Al}$ have been recently determined [1-3] and revealed a large homogeneity region for the ternary Laves phase with $\mathrm{MgZn}_{2}$-type structure: $\mathrm{Ti}\left(\mathrm{Ti}_{y} \mathrm{Ni}_{x} \mathrm{Al}_{1-x-y}\right)_{2}$. The "boomerang-like" shape of the phase field in the isothermal section at $900{ }^{\circ} \mathrm{C}$ suggests a complicated atom site exchange mechanism. As precise thermodynamic calculations of phase equilibria require the exact atom site occupation among the various sublattices of the crystal structure of compounds and solution phases, a detailed investigation of the atom distribution in the ternary Laves phase $\operatorname{Ti}\left(\mathrm{Ti}_{y} \mathrm{Ni}_{x} \mathrm{Al}_{1-x-y}\right)_{2}$ became the subject of the present investigation. In addition heat of formation data were determined from drop calorimetry as well as from first principles ab-inito ground state energy calculations. 


\section{Experimental details}

For combined X-ray and neutron diffraction, alloys with nominal composition $\mathrm{Ti}_{0.34} \mathrm{Ni}_{0.18} \mathrm{Al}_{0.48}, \mathrm{Ti}_{0.36} \mathrm{Ni}_{0.24} \mathrm{Al}_{0.40}$, $\mathrm{Ti}_{0.40} \mathrm{Ni}_{0.27} \mathrm{Al}_{0.33}$ and $\mathrm{Ti}_{0.44} \mathrm{Ni}_{0.27} \mathrm{Al}_{0.29}$ with a weight of 10 grams each were prepared by argon arc-melting (weight loss less than $0.1 \%$ ) on a water-cooled copper hearth in Ti-gettered argon from elemental ingots with a minimal purity of $99.9 \mathrm{wt} \%$. A series of smaller alloy specimens $(1 \mathrm{~g}$ each) were arc-melted to elucidate details in the phase relations at $1000{ }^{\circ} \mathrm{C}$ concerning the Ti-rich Laves phase. All alloys were sealed in quartz tubes and annealed at $1000{ }^{\circ} \mathrm{C}$ for $240 \mathrm{~h}$ before quenching in cold water. Single crystals were mechanically isolated from crushed as-cast alloys. Inspection on an AXS-GADDS texture goniometer assured high crystal quality, unit cell dimensions and Laue symmetry of the specimens prior to $\mathrm{X}$-ray intensity data collection on a four-circle Nonius Kappa diffractometer equipped with a CCD area detector employing graphite monochromated $\mathrm{MoK}_{\alpha}$ radiation $(\lambda=0.071073 \mathrm{~nm})$. Orientation matrix and unit cell parameters were derived using the program DENZO [4]. No absorption corrections were necessary because of the rather regular crystal shape and small dimensions of the investigated specimens. The structures were solved by direct methods and refined with the SHELXL-97 and SHELXS-97 program [5].

X-ray powder diffraction data from as-cast and annealed alloys were collected employing a Guinier-Huber image plate system with $\mathrm{Cu} K_{\alpha_{1}}\left(8^{\circ}<2 \theta<100^{\circ}\right)$. Precise lattice parameters were calculated by least-squares fits to the indexed $4 \theta$-values employing $\mathrm{Ge}$ as internal standard $\left(a_{\mathrm{Ge}}=0.5657906 \mathrm{~nm}\right)$. Samples for neutron powder diffraction were powdered to a grain size below $40 \mu \mathrm{m}$ in order to reduce preferential orientation effects. Neutron diffraction was performed at room temperature on the high-resolution HRPT diffractometer [6] at the SINQ spallation source of the Paul Scherrer Institute, Switzerland, in high intensity mode $\left(\Delta d / d \geq 2 \times 10^{-3}\right)$ with a neutron wavelength $\lambda_{\text {neutron }}=0.1494 \mathrm{~nm}$ within the angular $2 \theta$ range from $5^{\circ}$ to $165^{\circ}$. Quantitative Rietveld refinement of the X-ray and neutron powder diffraction data was performed with the FULLPROF program [7], employing internal tables for scattering lengths and atomic form factors (Ti: -0.3438; Ni: 1.0300; Al: 0.3449).

The as cast and annealed samples were polished using standard procedures and were examined for single-phase condition by optical metallography and scanning electron microscopy (SEM). Compositions were determined via Electron Probe Micro-Analyses (EPMA) on a Cambridge stereoscan equipped with a microprobe Oxford model $\mathrm{Si}(\mathrm{Li})$-Tetralink pentafet. A peak from a cobalt-standard was used via a calibration procedure in order to monitor beam current, gain and resolution of the spectrometer. Pure elements were used as standards to carry out the deconvolution of overlapping peaks and background subtraction. Finally the X-ray intensities were corrected for ZAF effects using the INCA-Energy 300 software package [8]. Overall composition of the samples after EPMA agree with the nominal values within 0.5 at $\%$.
The heat of dissolutions of the alloys $\mathrm{Ti}_{0.34} \mathrm{Ni}_{0.18} \mathrm{Al}_{0.48}$ and $\mathrm{Ti}_{0.36} \mathrm{Ni}_{0.24} \mathrm{Al}_{0.40}$ as well as of pure $\mathrm{Ni}$ and $\mathrm{Ti}$ were measured using an isoperibolic calorimeter by dropping the solid samples at room temperature (i.e. $298 \mathrm{~K}$ ) into liquid aluminium at a temperature of $1409 \pm 5 \mathrm{~K}$. Experimental techniques and the method of evaluation of the integral enthalpy of formation of liquid dilute alloys (referring to standard temperature $(298.15 \mathrm{~K})$ ) were described in our previous paper [9]. The value for the enthalpy change upon heating of pure aluminium from room temperature to $1409 \pm 5 \mathrm{~K}\left(\Delta H_{298, \mathrm{Al}}^{1409}\right)$ was taken from the SGTE data for pure elements [10]. Note, that this value is required for determination of a calibration factor (heat equivalent) of the calorimeter used as well as for evaluation of standard heat of formation of intermetallics investigated.

$A b$-initio calculations were performed using the Vienna ab-initio simulation package (VASP) [11] with the projector augmented wave potential (PAW) construction [12]. For the exchange-correlation functional the generalized gradient approximation (GGA) of Perdew and Wang [13] was applied. Brillouin-zone integrations were performed for suitably large sets of special $k$ points according to Monkhorst and Pack [14]. An overall energy cutoff of $400 \mathrm{eV}$ was chosen. For $\mathrm{Ti}$ and $\mathrm{Ni}$ the semi-core $3 \mathrm{p}$ states were treated as valence states. Optimization of geometrical parameters (atomic position and lattice parameters) was achieved by minimizing forces and total energies. The $c / a$ ratio for the hexagonal phase with $\mathrm{MgZn}_{2}$-type (C14) was optimized by a stress tensor technique which simultaneously allows structural relaxations.

\section{Results and discussion}

\section{Homogeneity region and crystal structure of the Laves phase}

The as-cast samples $\mathrm{Ti}_{0.34} \mathrm{Ni}_{0.18} \mathrm{Al}_{0.48}$ and $\mathrm{Ti}_{0.36} \mathrm{Ni}_{0.24} \mathrm{Al}_{0.40}$ were single-phase. Only a slight variation in composition was observed by EPMA revealing the compositions $\mathrm{Ti}_{0.348} \mathrm{Ni}_{0.184} \mathrm{Al}_{0.468}$ and $\mathrm{Ti}_{0.367} \mathrm{Ni}_{0.243} \mathrm{Al}_{0.390}$. These alloys were used for the neutron diffraction experiment in as-cast conditions. As-cast alloys from the Ti-rich part of the single-phase region of the Laves phase at $900{ }^{\circ} \mathrm{C}$ [1] were found to be inhomogeneous suggesting incongruent formation of the Laves phase. In order to determine the Ti-rich end of the homogeneity region of the ternary Laves phase $\mathrm{Ti}\left(\mathrm{Ti}_{y} \mathrm{Ni}_{x} \mathrm{Al}_{1-x-y}\right)_{2}$, several alloys were studied by EMPA and $\mathrm{X}$-ray diffraction in as-cast condition as well as after anneal at $1000^{\circ} \mathrm{C}$.

Whereas as cast alloys $\mathrm{Ti}_{0.46} \mathrm{Ni}_{0.29} \mathrm{Al}_{0.25}$ (EMPA area scan $\mathrm{Ti}_{0.462} \mathrm{Ni}_{0.289} \mathrm{Al}_{0.251}$ ) show primary dendrites of the Laves phase with composition $\mathrm{Ti}_{0.40} \mathrm{Ni}_{0.28} \mathrm{Al}_{0.32}$, annealing reveals a three-phase structure with a Ti-rich Laves phase $\mathrm{Ti}_{0.456} \mathrm{Ni}_{0.281} \mathrm{Al}_{0.263}$ and minor phases $\mathrm{Ti}_{2} \mathrm{Ni}$ $\left(\mathrm{Ti}_{0.529} \mathrm{Ni}_{0.310} \mathrm{Al}_{0.161}\right)+\mathrm{TiNi}_{2} \mathrm{Al}$. The alloy $\mathrm{Ti}_{0.52} \mathrm{Ni}_{0.22} \mathrm{Al}_{0.26}$ annealed at $1000{ }^{\circ} \mathrm{C}$ reveals a Laves phase $\mathrm{Ti}_{0.463} \mathrm{Ni}_{0.273} \mathrm{Al}_{0.264}$ with small amounts of $\mathrm{Ti}_{2} \mathrm{Ni}$ and $\mathrm{Ti}_{3} \mathrm{Al}$ $\left(\mathrm{Ti}_{0.725} \mathrm{Ni}_{0.007} \mathrm{Al}_{0.268}\right)$. Thus the Ti-rich boundary of the Laves phase at $1000{ }^{\circ} \mathrm{C}$, located at $\mathrm{Ti}_{0.463} \mathrm{Ni}_{0.273} \mathrm{Al}_{0.264}$, in good 
agreement with the data [1] reporting $\mathrm{Ti}_{0.43} \mathrm{Ni}_{0.27} \mathrm{Al}_{0.30}$ as the Ti-rich limit at $900^{\circ} \mathrm{C}$. Phase equilibria at $1000^{\circ} \mathrm{C}$, however, are different. Whilst the Laves phase $\left(\tau_{3}\right)$ forms a three-phase equilibrium with $\mathrm{Ti}_{3} \mathrm{Al}\left(\alpha_{2}\right)$ and $\mathrm{TiNi}_{2} \mathrm{Al}\left(\tau_{4}\right)$ at $900{ }^{\circ} \mathrm{C}$ [1], alloys annealed at $1000^{\circ} \mathrm{C}$ contain the Laves phase together with the $\mathrm{Ti}_{2} \mathrm{Ni}$ based solid solution. Our reinvestigation of the phase equilibria in this part of the ternary system in the temperature range from solidus to $800{ }^{\circ} \mathrm{C}$ shows a rather complicated reaction scheme on cooling that involves the formation of new phase $\mathrm{Ti}_{47-49} \mathrm{Ni}_{27} \mathrm{Al}_{26-24}\left(\tau_{5}\right)$. This phase exists in a small temperature range from $\sim 865$ to $985^{\circ} \mathrm{C}$ and forms equilibria with $\tau_{4},(\mathrm{Ti}, \mathrm{Al})_{2} \mathrm{Ni}$ and $\alpha_{2} . \tau_{5}$ decomposes with formation of $\alpha_{2}$ and $\tau_{4}$. Details will be presented as part of a forthcoming work.

Due to the incongruent solidification of the Laves phase at high Ti-contents, we were not able to produce a suitable single crystal for X-ray single crystal investigations whilst single crystals were easily selected from ascast Al-rich alloys $\mathrm{Ti}_{0.34} \mathrm{Ni}_{0.18} \mathrm{Al}_{0.48}$ and $\mathrm{Ti}_{0.36} \mathrm{Ni}_{0.24} \mathrm{Al}_{0.40}$. Once the Ti-rich limit of the Laves-phase was established at $1000{ }^{\circ} \mathrm{C}$, alloys with compositions $\mathrm{Ti}_{0.40} \mathrm{Ni}_{0.27} \mathrm{Al}_{0.33}$ and $\mathrm{Ti}_{0.44} \mathrm{Ni}_{0.27} \mathrm{Al}_{0.29}$ were annealed at $1000{ }^{\circ} \mathrm{C}$ and subjected to detailed investigation by X-ray and neutron powder diffraction.

In a first attempt to reveal the atom occupation in the Laves phase, two small single crystals were extracted from the large Al-rich alloy specimens with nominal composition $\mathrm{Ti}_{0.34} \mathrm{Ni}_{0.18} \mathrm{Al}_{0.48}$ and $\mathrm{Ti}_{0.36} \mathrm{Ni}_{0.24} \mathrm{Al}_{0.40}$. Systematic extinctions $(00 l)$ for $l=2 n+1$ and $(h h l)$ for $l=2 n+1$ pointed towards space group $P 6_{3} / m m c$ as the one with the highest point symmetry, which was further on adopted throughout the evaluation of the crystal structure. X-ray single crystal structure determination via direct methods yielded the occupation of three Wyckoff positions $2 a$, $4 f$ and $6 h$ with atom parameters suggesting isotypism with the $\mathrm{MgZn}_{2}$-type Laves structure. Subsequent refinement in accordance with the given alloy composition, however, resulted in a series of model structures (all in space group $P 6_{3} / \mathrm{mmc}$ ) which all yielded rather low residual values ranging from $R_{\mathrm{F}}^{2}=\sum\left|F_{\mathrm{o}}^{2}-F_{\mathrm{c}}^{2}\right| / \sum F_{\mathrm{o}}^{2}=0.017$ to 0.038 (see Table 1). The small differences in $R_{\mathrm{F}}{ }^{2}$ were at that stage not considered to be decisive to define the true atom site occupation, particularly as in the X-ray refinement a proper random mixture of $\mathrm{Ni} / \mathrm{Al}$ atoms may constitute a pseudo-titanium atom with identical electron density of 22 electrons per site. In order to elucidate the true atom distribution neutron powder diffraction experiments were performed, exploiting the fact of a negative neutron scattering length for natural titanium atoms.

Table 1. Comparison of various structure models from X-ray structure determination for the two single crystals $\mathrm{Ti}_{0.34} \mathrm{Ni}_{0.18} \mathrm{Al}_{0.48}$ and $\mathrm{Ti}_{0.36} \mathrm{Ni}_{0.24} \mathrm{Al}_{0.40}$ (all in space group $P 6_{3} / m m c$ ).

\begin{tabular}{lllllll}
\hline Site & $\mathrm{Ti}_{0.34} \mathrm{Ni}_{0.18} \mathrm{Al}_{0.48}$ & \multicolumn{4}{l}{$\mathrm{Ti}_{0.36} \mathrm{Ni}_{0.24} \mathrm{Al}_{0.40}$} \\
\hline $2 a$ & $\mathrm{Al}, \mathrm{Ni}$ & $\mathrm{Al}, \mathrm{Ti}$ & $\mathrm{Al}$ & $\mathrm{Al}, \mathrm{Ti}$ & $\mathrm{Al}, \mathrm{Ti}$ & $\mathrm{Al}, \mathrm{Ni}$ \\
$4 f$ & $\mathrm{Ti}$ & $\mathrm{Al}, \mathrm{Ni}$ & $\mathrm{Al}, \mathrm{Ni}$ & $\mathrm{Al}, \mathrm{Ni}$ & $\mathrm{Ti}$ & $\mathrm{Ti}$ \\
$6 h$ & $\mathrm{Al}, \mathrm{Ni}$ & $\mathrm{Al}, \mathrm{Ti}$ & $\mathrm{Al}, \mathrm{Ti}$ & $\mathrm{Al}, \mathrm{Ti}$ & $\mathrm{Al}, \mathrm{Ni}$ & $\mathrm{Al}, \mathrm{Ni}, \mathrm{Ti}$ \\
$R_{\mathrm{F}}{ }^{2}$ & 0.017 & 0.027 & 0.038 & 0.030 & 0.022 & 0.018 \\
\hline
\end{tabular}

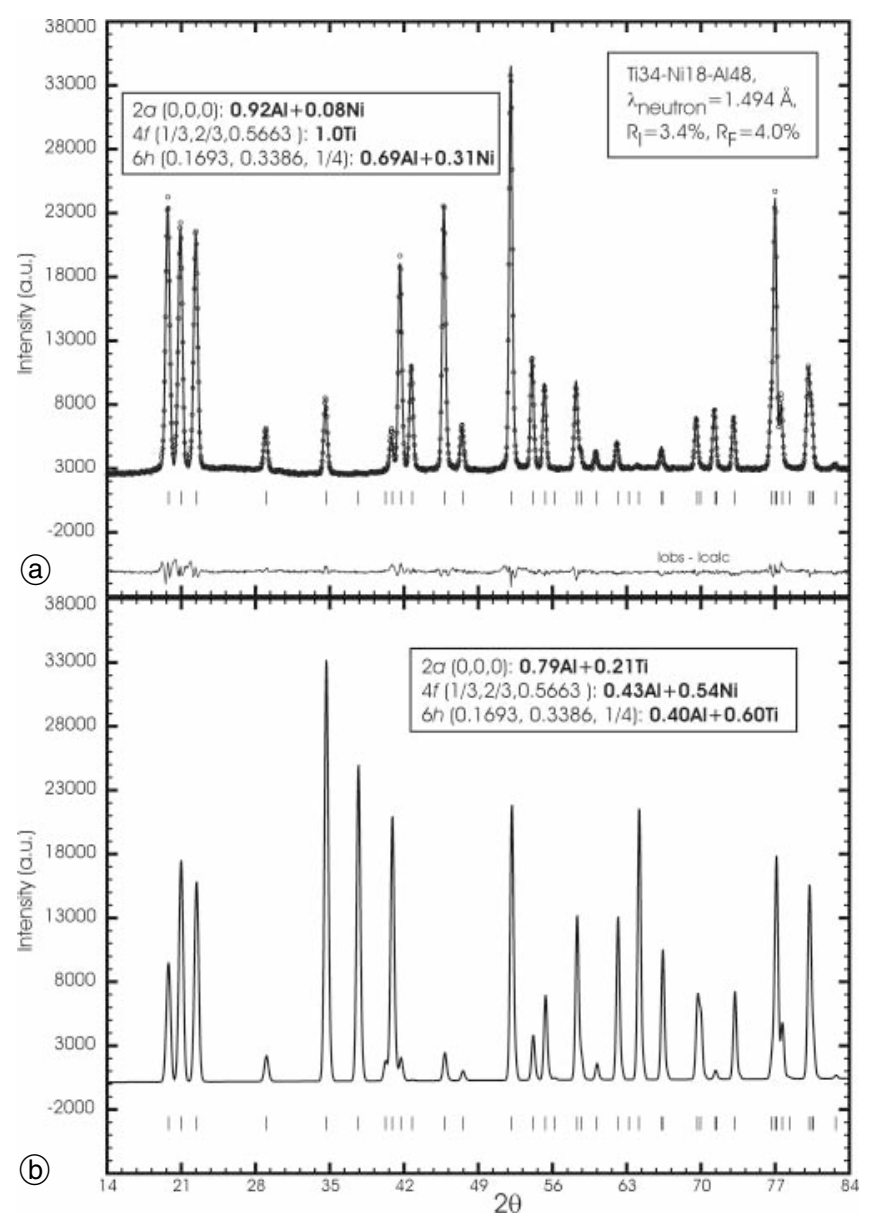

Fig. 1. Results of Rietveld refinement (neutron diffraction data) for the $\mathrm{MgZn}_{2}$-type Laves phases, $\mathrm{Ti}_{0.34} \mathrm{Ni}_{0.18} \mathrm{Al}_{0.48}$ (a) and (b) theoretical profile for this composition based on model with $\mathrm{Ni} / \mathrm{Al}$ statistic in the $4 f$ site (see Table 1 ).

Refinements of the neutron intensity data (Fig. 1, Tables $2 \mathrm{a}$ and $2 \mathrm{~b}$ ) resulted in a partially ordered atom arrangement for all investigated compositions $\operatorname{Ti}_{(}\left(\mathrm{Ti}_{y} \mathrm{Ni}_{x} \mathrm{Al}_{1-x-y}\right)_{2}$ : in all cases the titanium atoms were unambiguously located in the $4 f$ positions, whilst $\mathrm{Ni} / \mathrm{Al}$ share the sites in $2 a$ and $6 h$ at different mixing levels (partial site preference). Attempts to alternatively place the main amount of the Tiatoms in the $2 a$ or $6 h$ sites and to simultaneously fill the $4 f$ site entirely with $\mathrm{Ni} / \mathrm{Al}$ were ruled out due to high residual values (Fig. 1b). Combined Rietveld refinements of neutron and X-ray powder diffraction data for Ti-rich Laves phases (Table 2a) unambiguously reveal the remaining Ti-atoms to share $2 a$ and $6 h$ sites with $\mathrm{Ni}$ and $\mathrm{Al}$ atoms. No deviations from symmetry $P 6_{3} / m m c$ were encountered. As a significant result, Rietveld refinements leave no room for Al- or Ni-atoms in the Ti-sublattice ( $4 f$ sites). These findings were finally used as a guideline for X-ray refinement of the single crystal data yielding a correspondingly low $R$-value thereby confirming the atom arrangement defined by the neutron data. Both, neutron and X-ray intensity data refinements converged to compositions in close agreement to the nominal as well as to the composition obtained from EMPA. Results of the structure determination are listed in Tables 2a and 2b. Finally it shall be noted that the atom site occupations defined by neutron diffraction for both Laves phase compositions investigated by X-ray single 
Table 2a. Structural data for Laves phase in ternary systems Ti-Ni-Al $\left(\mathrm{MgZn}_{2}\right.$-type, space group $P 6_{3} / m m c ; \mathrm{No}$. 194) ${ }^{a}$.

\begin{tabular}{|c|c|c|c|c|}
\hline \multirow{2}{*}{$\begin{array}{l}\text { Alloy composition } \\
\text { Formula from EMPA }\end{array}$} & \multicolumn{2}{|c|}{$\mathrm{Ti}_{0.34} \mathrm{Ni}_{0.18} \mathrm{Al}_{0.48}$, as-cast } & \multicolumn{2}{|c|}{$\mathrm{Ti}_{0.36} \mathrm{Ni}_{0.24} \mathrm{Al}_{0.40}$, as-cast } \\
\hline & $\mathrm{Ti}_{0.348} \mathrm{Ni}_{0.184} \mathrm{Al}_{0.468}$ & & $\mathrm{Ti}_{0.367} \mathrm{Ni}_{0.243} \mathrm{Al}_{0.390}$ & \\
\hline Formula from refinement & $\mathrm{Ti}_{0.333} \mathrm{Ni}_{0.185} \mathrm{Al}_{0.482}$ & $\mathrm{Ti}_{0.333} \mathrm{Ni}_{0.168} \mathrm{Al}_{0.499}$ & $\mathrm{Ti}_{0.360} \mathrm{Ni}_{0.245} \mathrm{Al}_{0.395}$ & $\mathrm{Ti}_{0.36} \mathrm{Ni}_{0.24} \mathrm{Al}_{0.40}$ \\
\hline Data collection & Nonius KappaCCD & Neutrons & Nonius KappaCCD & Neutrons \\
\hline Radiation & $\operatorname{Mo} K_{\alpha}$ & $\lambda=0.1494 \mathrm{~nm}$ & $\operatorname{Mo} K_{\alpha}$ & $\lambda=0.1494 \mathrm{~nm}$ \\
\hline $2 \theta$ range & $2<2 \theta<72.45$ & $4.5<2 \theta<85.0$ & $2<2 \theta<72.45$ & $2<2 \theta<85.0$ \\
\hline Crystal size & $28 \times 28 \times 28 \mu \mathrm{m}^{3}$ & - & $14 \times 21 \times 28 \mu \mathrm{m}^{3}$ & - \\
\hline$a[\mathrm{~nm}]$ & $0.50189(2)$ & $0.50129(1)$ & $0.50070(2)$ & $0.50031(2)$ \\
\hline$c[\mathrm{~nm}]$ & $0.82050(3)$ & $0.81956(3)$ & $0.80697(4)$ & $0.80667(3)$ \\
\hline$a[\mathrm{~nm}]$, Guinier & - & $0.50149(4)$ & - & $0.50060(1)$ \\
\hline$c[\mathrm{~nm}]$, Guinier & - & $0.81939(5)$ & - & $0.80682(3)$ \\
\hline Reflections in refinement & $172 F_{\mathrm{o}}>4 \sigma\left(F_{\mathrm{o}}\right)$ of 195 & 38 & $167 F_{\mathrm{o}}>4 \sigma\left(F_{\mathrm{o}}\right)$ of 192 & 38 \\
\hline Number of variables & 15 & 19 & 15 & 19 \\
\hline$R_{F}^{2}=\sum\left|F_{\mathrm{o}}^{2}-F_{\mathrm{c}}^{2}\right| / \sum F_{\mathrm{o}}^{2}$ & 0.0180 & $R_{I}=0.0336$ & 0.0170 & $R_{I}=0.0412$ \\
\hline$R_{\mathrm{Int}}$ & 0.0175 & $R_{F}=0.0401$ & 0.0224 & $R_{F}=0.0419$ \\
\hline GOF & 1.074 & $R_{P}=0.0254$ & 0.636 & $R_{P}=0.0325$ \\
\hline Extinction (Zachariasen) & $0.019(6)$ & $R_{w P}=0.0303$ & $0.013(3)$ & $R_{w P}=0.0388$ \\
\hline M1 in $2 a(0,0,0)$; occ. & $0.117(3) \mathrm{Ni}+0.883(3) \mathrm{Al}$ & $0.079(2) \mathrm{Ni}+0.921 \mathrm{Al}$ & $0.431(4) \mathrm{Ni}+0.569 \mathrm{Al}$ & $0.359(3) \mathrm{Ni}+0.642 \mathrm{Al}$ \\
\hline$U_{11}^{b}=U_{22}$ & $0.0145(4)$ & $B_{\text {iso }}=0.71(5)^{c}$ & $0.0125(3)$ & $B_{\text {iso }}=0.60(4)^{c}$ \\
\hline$U_{33} ; U_{12}$ & $0.0080(5) ; 0.0072(2)$ & & $0.0086(4) ; 0.0063(2)$ & \\
\hline $\mathrm{Ti}$ in $4 f(1 / 3,2 / 3, z)$; occ. & $z=0.56593(6) ; 1.00 \mathrm{Ti}$ & $z=0.5663(2) ; 1.00(4) \mathrm{Ti}$ & $z=0.56451(7) ; 1.00 \mathrm{Ti}$ & $z=0.5648(2) ; 1.00(5) \mathrm{Ti}$ \\
\hline$U_{11}=U_{22}$ & $0.0073(2)$ & $B_{\text {iso }}=0.60(3)^{c}$ & $0.0070(2)$ & $B_{\text {iso }}=0.68(4)^{c}$ \\
\hline$U_{33} ; U_{12}$ & $0.0074(3) ; 0.0036(1)$ & & $0.0081(2) ; 0.0040(1)$ & \\
\hline M3 in $6 h(x, 2 x, 1 / 4)$ & $x=0.16964(5)$ & $x=0.1693(2)$ & $x=0.17082(6)$ & $x=0.1707(2)$ \\
\hline$U_{11} ; U_{22}$ & $0.0134(3) ; 0.0079(3)$ & $B_{\text {iso }}=0.70(3)^{c}$ & $0.0111(2) ; 0.0064(3)$ & $B_{\text {iso }}=0.52(2)^{c}$ \\
\hline$U_{33} ; U_{12}$ & $0.0092(3) ; 0.0039(1)$ & & $0.0102(2) ; 0.0032(1)$ & \\
\hline $\begin{array}{l}\text { Residual electron density; } \\
\text { max; min in } \\
{\left[\text { electrons } / \mathrm{nm}^{3}\right] \times 1000}\end{array}$ & $0.62 ;-0.62$ & - & $0.57 ;-0.47$ & - \\
\hline
\end{tabular}

a: Crystal structure data are standardized using the program Structure Tidy [40];

b: Anisotropic atomic displacement parameters $U_{i j}$ in $\left[10^{2} \mathrm{~nm}^{2}\right]$;

c: Isotropic atomic displacement parameters $B_{\text {iso }}$ in $\left[10^{2} \mathrm{~nm}^{2}\right]$.

crystal technique, $\mathrm{Ti}_{0.34} \mathrm{Ni}_{0.18} \mathrm{Al}_{0.48}$ and $\mathrm{Ti}_{0.36} \mathrm{Ni}_{0.24} \mathrm{Al}_{0.40}$, essentially correspond to the models with the lowest $R_{\mathrm{F}}{ }^{2}$ values obtained from our first results for the X-ray single crystal determination in Table 1 .

The compositional dependences of the lattice parameters of the Laves phase are presented in Fig. 2 and show well developed extrema about 35 at $\% \mathrm{Al}$, that are associated with (i) similar extrema in the shape of the homogeneity region of this phase (Fig. 2c) and with (ii) compositional changes of the crystallographic parameters (Figs. 3 and 4). The observed dependences of the lattice parameters simply explain by the atom site preference in the crystal structure (Fig. 5): at Al-rich compositions the titanium atoms are located only in the $4 f$ site, the $2 a$ site prefers the aluminium atoms, whereas a statistical distribution of the $\mathrm{Al}$ and $\mathrm{Ni}$ atoms is determined for the $6 h$ site. With decreasing $\mathrm{Al}$ content a statistical distribution is encountered for both $2 a$ and $6 h$ sites, but the site preferences exhibit different trends with changing composition. Whilst the distribution of the atoms in the $2 a$ site is more compli- cated (Fig. 5a), practically linear dependences are observed for all three elements located in the $6 h$ site (Fig. 5b). One observes a significant decrease of the nickel content in the $2 a$ site when $\mathrm{Al}$ content changes from 50 to 40 at\%. This $\mathrm{Al} / \mathrm{Ni}$ substitution is responsible for the observed decrease of the lattice parameters (Fig. 2) throughout the compositional range. With further decrease of the $\mathrm{Al}$ content the amount of the $\mathrm{Ni}$ atoms in the $2 a$ site is almost constant, whereas the $\mathrm{Ti}$ atoms start to substitute for aluminium. This trend is associated with an increase of the lattice parameters at the Ti-rich side of the homogeneity region of the Laves phase. Similar considerations are able to explain the "boomerang-like" shape of the homogeneity region of the Laves phase. Compositional dependences of the interatomic distances (Fig. 4) show minima at about $35 \mathrm{at} \% \mathrm{Al}$, in good agreement with the change of the lattice parameters (Fig. 2). The only exception concerns the distance M3-M3 that shows a maximum (Fig. 4a) and it corresponds to a maximum in the dependence of the atomic coordinates for M3 atoms (the $6 h$ site, Fig. 3). It is 
Table 2b. Results of the multy-patterns Rietveld refinements of powder diffraction data for Laves phase in ternary systems $\mathrm{Ti}-\mathrm{Ni}-\mathrm{Al}\left(\mathrm{MgZn} \mathrm{n}^{-}\right.$ type, space group $P 6_{3} / m m c$; No. 194) $)^{a}$.

\begin{tabular}{|c|c|c|c|c|}
\hline \multirow{2}{*}{$\begin{array}{l}\text { Alloy composition } \\
\text { Formula from refinement }\end{array}$} & \multicolumn{2}{|c|}{$\mathrm{Ti}_{0.40} \mathrm{Ni}_{0.27} \mathrm{Al}_{0.33}$, annealed at $1000{ }^{\circ} \mathrm{C}$} & \multicolumn{2}{|c|}{$\mathrm{Ti}_{0.44} \mathrm{Ni}_{0.27} \mathrm{Al}_{0.29}$, annealed at $1000^{\circ} \mathrm{C}$} \\
\hline & \multicolumn{2}{|c|}{$\mathrm{Ti}_{0.398} \mathrm{Ni}_{0.270} \mathrm{Al}_{0.332}$} & \multicolumn{2}{|c|}{$\mathrm{Ti}_{0.436} \mathrm{Ni}_{0.269} \mathrm{Al}_{0.295}$} \\
\hline Data collection; & Neutrons & Image Plate & Neutrons & Image Plate \\
\hline Radiation & $\lambda=0.1494 \mathrm{~nm}$ & $\mathrm{Cu} K_{\alpha}$ & $\lambda=0.1494 \mathrm{~nm}$ & $\mathrm{Cu} K_{\alpha}$ \\
\hline $2 \theta$ range & $5.0<2 \theta<164.9$ & $8.0<2 \theta<100.0$ & $5.0<2 \theta<164.9$ & $8.0<2 \theta<100.0$ \\
\hline$a[\mathrm{~nm}]$ & $0.500683(4)$ & $0.500542(4)$ & $0.501274(3)$ & $0.501272(3)$ \\
\hline$c[\mathrm{~nm}]$ & $0.805718(9)$ & $0.805518(8)$ & $0.807250(8)$ & $0.807273(5)$ \\
\hline$a[\mathrm{~nm}]$, Guinier & $0.50059(2)$ & $0.50059(2)$ & $0.50129(3)$ & $0.50129(3)$ \\
\hline$c$ [nm], Guinier & $0.80547(5)$ & $0.80547(5)$ & $0.80705(7)$ & $0.80705(7)$ \\
\hline Reflections in refinement & 107 & 53 & 107 & 53 \\
\hline Number of variables & 33 & 33 & 33 & 33 \\
\hline$R_{F}=\sum\left|F_{\mathrm{o}}-F_{\mathrm{c}}\right| / \sum F_{\mathrm{o}}$ & 0.061 & 0.098 & 0.082 & 0.091 \\
\hline$R_{I}=\sum\left|I_{\mathrm{o}}-I_{\mathrm{c}}\right| / \sum I_{\mathrm{o}}$ & 0.078 & 0.087 & 0.099 & 0.082 \\
\hline$R_{w P}=\left[\sum w_{i}\left|y_{o i}-y_{c i}\right|^{2} / \sum w_{i}\left|y_{o i}\right|^{2}\right]^{1 / 2}$ & 0.064 & 0.064 & 0.073 & 0.076 \\
\hline$R_{P}=\sum\left|y_{o i}-y_{c i}\right| / \sum\left|y_{o i}\right|$ & 0.043 & 0.043 & 0.046 & 0.047 \\
\hline$\left.R_{e}=\left[(N-P+C) / \sum w_{i} y_{o i}^{2}\right)\right]^{1 / 2}$ & 0.020 & 0.020 & 0.012 & 0.012 \\
\hline$\chi^{2}=\left(R_{w P} / R_{e}\right)^{2}$ & 9.95 & 10.2 & 40.6 & 43.0 \\
\hline M1 in $2 a(0,0,0)$; occ. & \multicolumn{2}{|c|}{$0.075(5) \mathrm{Ti}+0.415 \mathrm{Ni}+0.510 \mathrm{Al}$} & \multicolumn{2}{|c|}{$0.206(6) \mathrm{Ti}+0.414 \mathrm{Ni}+0.380 \mathrm{Al}$} \\
\hline$B_{\text {iso }},\left[10^{2} \mathrm{~nm}^{2}\right]$ & \multicolumn{2}{|c|}{$0.53(2)$} & \multicolumn{2}{|c|}{$0.61(3)$} \\
\hline Ti in $4 f(1 / 3,2 / 3, z)$; occ. & \multicolumn{2}{|c|}{$0.99(2) \mathrm{Ti}, 0.5652(1)$} & \multicolumn{2}{|c|}{$1.00(1) \mathrm{Ti}, 0.5649(1)$} \\
\hline$B_{\text {iso }},\left[10^{2} \mathrm{~nm}^{2}\right]$ & \multicolumn{2}{|c|}{$0.54(2)$} & \multicolumn{2}{|c|}{$0.32(2)$} \\
\hline M3 in $6 h(x, 2 x, 1 / 4)$ & \multicolumn{2}{|c|}{$0.1709(2)$} & \multicolumn{2}{|c|}{$0.1705(3)$} \\
\hline occ. & \multicolumn{2}{|c|}{$0.105(2) \mathrm{Ti}+0.402 \mathrm{Ni}+0.493 \mathrm{Al}$} & \multicolumn{2}{|c|}{$0.145(3) \mathrm{Ti}+0.402 \mathrm{Ni}+0.453 \mathrm{Al}$} \\
\hline$B_{\text {iso }},\left[10^{2} \mathrm{~nm}^{2}\right]$ & \multicolumn{2}{|c|}{$0.48(1)$} & \multicolumn{2}{|c|}{$0.62(2)$} \\
\hline
\end{tabular}

a: Crystal structure data are standardized using the program Structure Tidy [40]

interesting to note that the substitution mechanism in the Laves phase mainly affects the $c$-lattice parameter (Fig. 2b) and the distance M2-M3 (Fig. 4b).

Finally, we have to mention that the Laves phase in the ternary system $\mathrm{Ti}-\mathrm{Ni}-\mathrm{Al}$ is the only truly ternary Laves
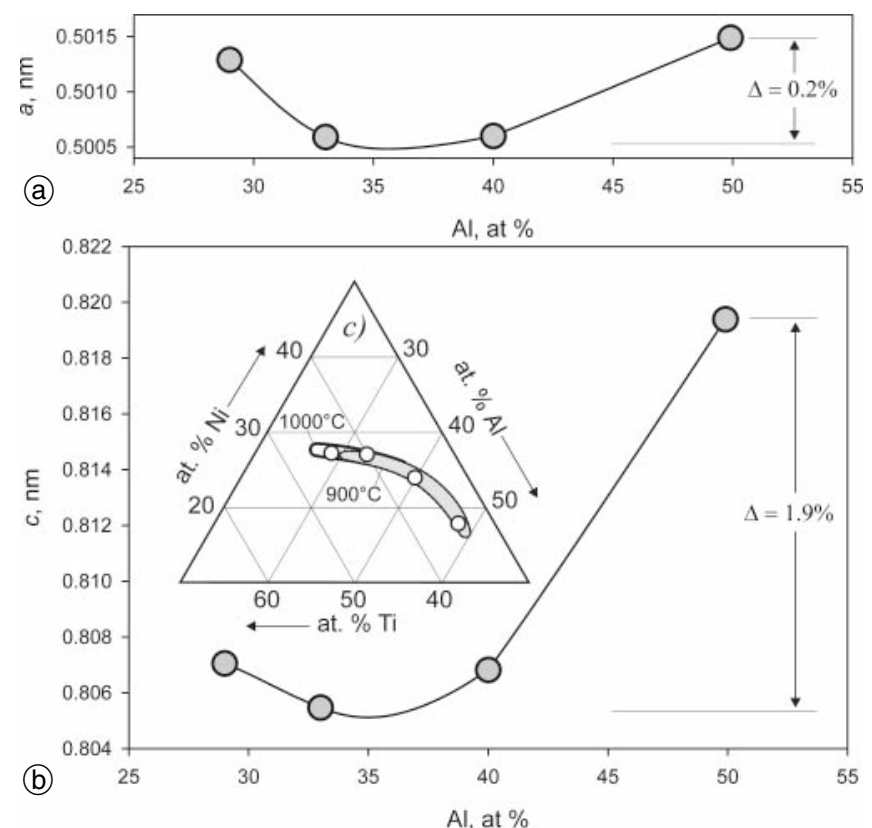

Fig. 2. Compositional dependences of the lattice parameters (a, b) and extension of the homogeneity region of the Laves phase (c) at $900{ }^{\circ} \mathrm{C}$ after [1] (filled aria) and at $1000{ }^{\circ} \mathrm{C}$ (solid line) for Ti rich end of solid solution. phase among known $\mathrm{Ti}-\mathrm{M}-\mathrm{Al}$ phase diagrams. No phases with Laves type structure are known for the corresponding binary boundary systems $\mathrm{Ti}-\mathrm{Ni}, \mathrm{Ti}-\mathrm{Al}$ and $\mathrm{Ni}-\mathrm{Al}$ in contrast to many $\mathrm{Ti}-\mathrm{M}-\mathrm{Al}$ systems that often contain ternary solid solutions extending from the binary Laves phases. Therefore, the discussed Laves phase may be considered as stabilization of the hypothetic binary Laves phases $\mathrm{TiAl}_{2}, \mathrm{TiNi}_{2}$ and $\mathrm{NiAl}_{2}$ by a third element. Experimental data collected for the ternary $\mathrm{Ti}-\mathrm{Ni}-\mathrm{Al}$ Laves phase in combination with ab-inito calculation can be extrapolated to these binary compositions in order to estimate their thermodynamic stability.

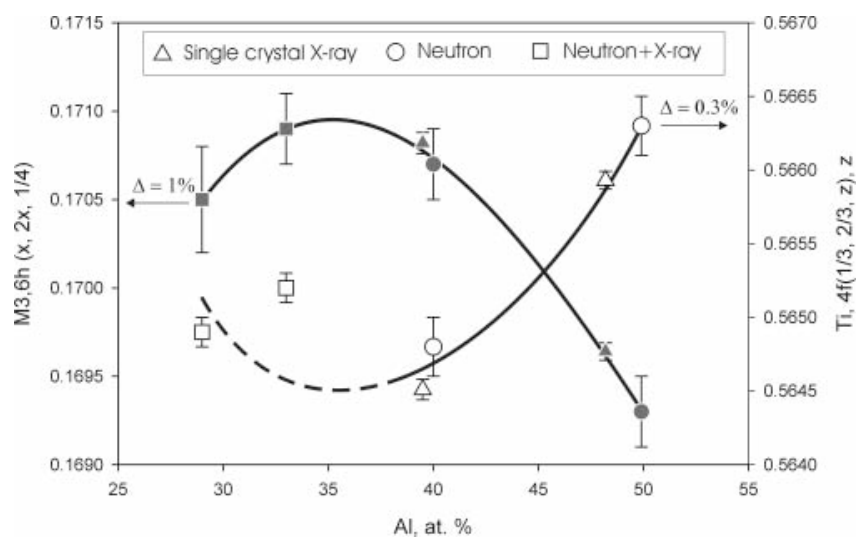

Fig. 3. Compositional dependences of the atomic coordinates of the Laves phase. 

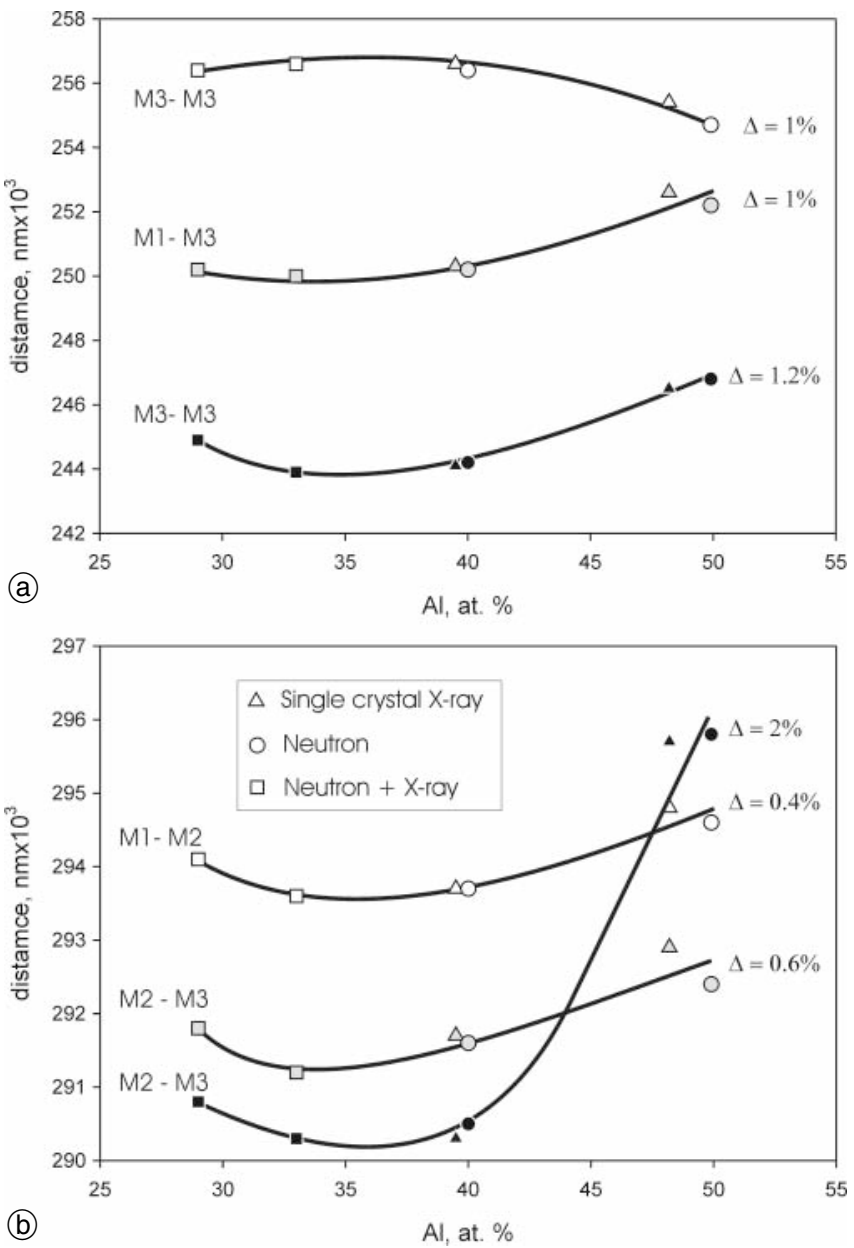

Fig. 4. Interatomic distances in the $\mathrm{Ti}-\mathrm{Ni}-\mathrm{Al}$ Laves phase.

\section{Heat of formation data from drop calorimetry}

The results from drop calorimetry concerning the enthalpy of formation of liquid dilute binary $\mathrm{Ni}-\mathrm{Al}, \mathrm{Ti}-\mathrm{Al}$ alloys and dilute ternary $\mathrm{Ti}-\mathrm{Ni}-\mathrm{Al}$ alloys (all referring to $298.15 \mathrm{~K}$ ) are shown in Figs. 6 and 7, respectively. It was observed that: (a) dropping samples of pure elements Ni, Ti, (see Figs. 6a and $6 \mathrm{~b}$, respectively) into liquid $\mathrm{Al}$ leads to exothermic reactions, whereas dissolution under the same conditions of both ternary intermetallics, $\mathrm{Ti}_{0.34} \mathrm{Ni}_{0.18} \mathrm{Al}_{0.48}$ and $\mathrm{Ti}_{0.36} \mathrm{Ni}_{0.24} \mathrm{Al}_{0.40}$, (see Figs. 7a and 7b, respectively) reveals endothermic effects; (b) the time of dissolution of pure Ti dropped into liquid Al increases practically twice in comparison with the previous drop whilst its exothermic heat effect decreases resulting in a concave character of the integral enthalpy curve (see Fig. 6a). Upon reaching the liquid-solid phase boundary (about 5 at\% $\mathrm{Ti}$ at $1409 \mathrm{~K}$ ) the evaluated enthalpy of dissolution reaches a value close to zero. Probably, the fast decrease of the enthalpy of dissolution of $\mathrm{Ti}$ is due to the loss of heat, when the dissolution process becomes enormously long. Therefore, data obtained for Ti can be successfully used for the evaluation of the partial enthalpy of dissolution of $\mathrm{Ti}$ in liquid $\mathrm{Al}$ at infinite dilution, but already at a concentration in excess of 1 at $\% \mathrm{Ti}$, they do not correctly characterise the interaction of dissimilar atoms.

It was found that the obtained integral values could be fitted properly using the following thermodynamically
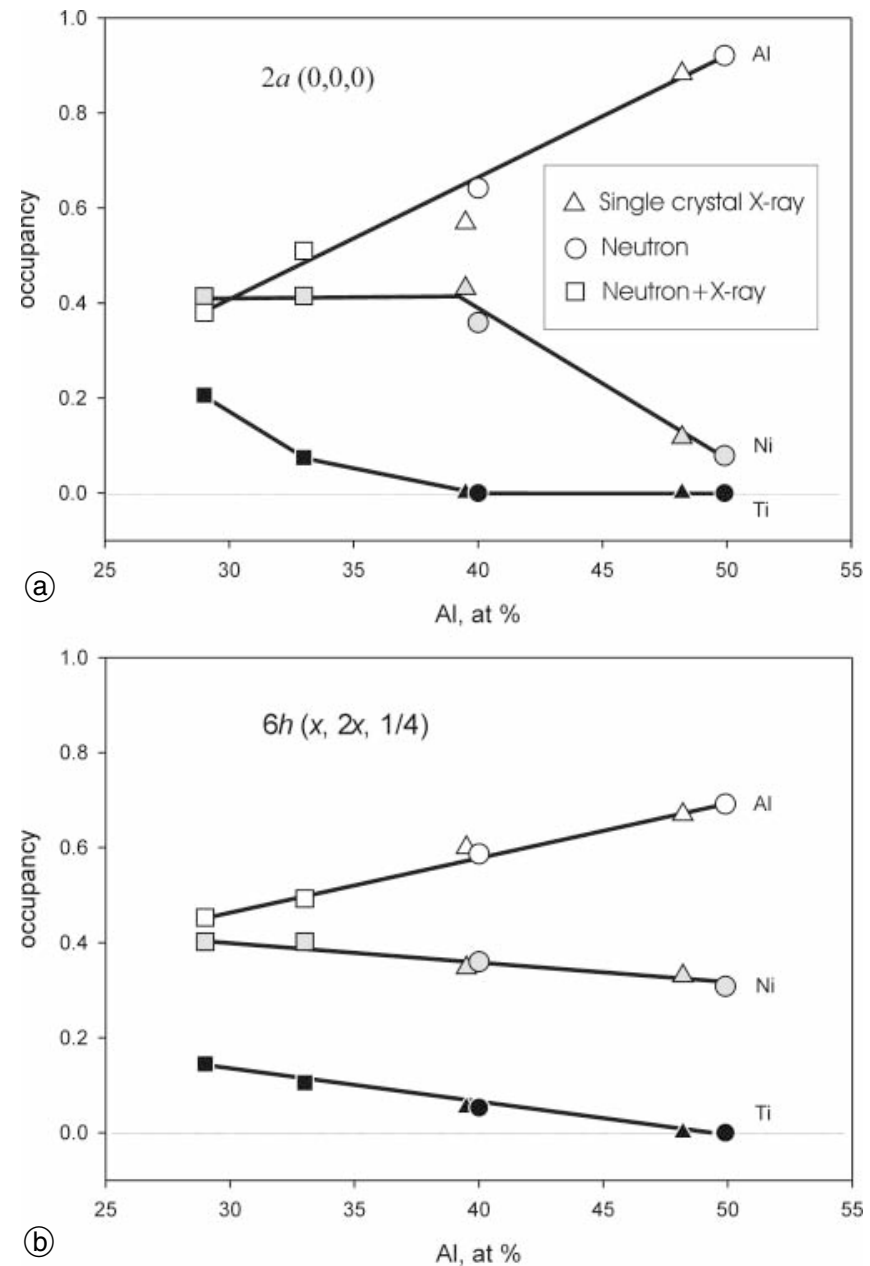

Fig. 5. Site preference for the $2 a$ and $6 h$ sites of the Laves phase. Note: the $4 f$ site contains only $\mathrm{Ti}$ atoms for all composition range.

adapted power series:

$$
\Delta H=x(1-x)\left(A+B x+C x^{2}\right)+(1-x) D
$$

where $A$ to $C$ are fitting parameters and $D$ corresponds to $\Delta H_{298, \mathrm{Al}}^{1409}$ according to Ref. [10]. The coefficient $A$ denotes the enthalpy of dissolution of the substance $i$ at infinite dilution $\left(\Delta_{\text {diss }} \bar{H}_{i}^{0}\right)$. The parameters $A$ of Eq. (1), as determined by least squares analysis are given in Table 3 .

The results obtained in the present work for the enthalpy of dissolutions of the pure elements can be compared with those from different authors measured at various temperatures [15-39]. For this purpose, the enthalpy changes upon heating of $\mathrm{Ni}$, Ti (evaluated using database [10]) were subtracted from the appropriate parameters $A$ (see Table 3 ) in order to refer them to equal standard states.

There are many reports dealing with the dissolution of nickel in liquid aluminium [15-20, 22, 23, 26, 27, 31-33]. All measurements were performed by calorimetry. The obtained data agree within about $\pm 5 \%$, which is close to the experimental error limit of high temperature drop calorimetry. It was found that all experimental results could be fitted by the following exponential growth equation:

$$
\Delta_{\text {diss }} H_{\mathrm{Ni}}^{0}=-139.6+0.35 \exp (T / 470)\left[\mathrm{kJ} \mathrm{mol}^{-1}\right] .
$$



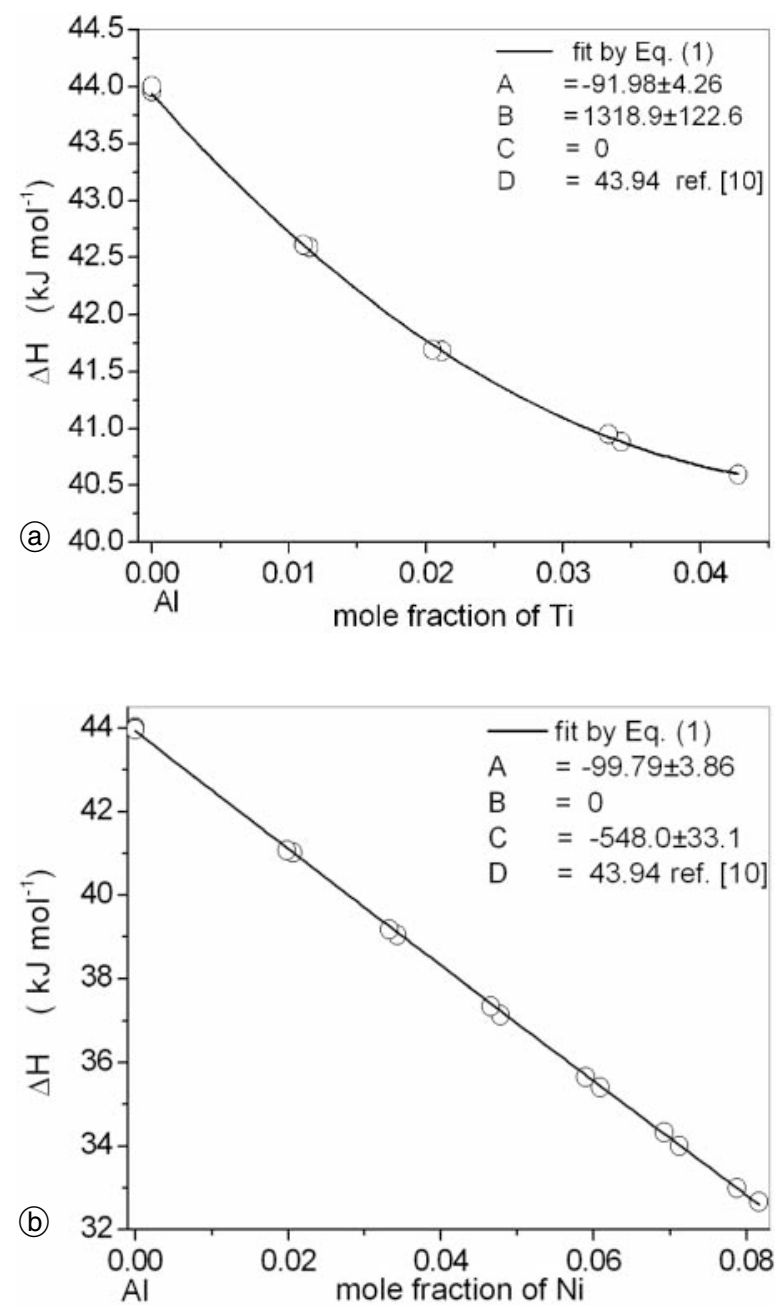

Fig. 6. Measured integral enthalpy of formation of liquid dilute binary alloys, $\mathrm{Ti}-\mathrm{Al}(\mathbf{a})$ and $\mathrm{Ni}-\mathrm{Al}(\mathbf{b})$, due to dropping of solid $\mathrm{Al}, \mathrm{Ti}$, $\mathrm{Ni}$ at $298 \mathrm{~K}$ into liquid $\mathrm{Al}$ at $1409 \pm 5 \mathrm{~K}$.

Several papers deal with the dissolution of titanium in liquid aluminium by calorimetry [24, 26-29]. The data of Batalin et al. [29] obtained at $1773 \mathrm{~K}$ differ strongly from values $[27,28]$ and lead to an enormously strong temperature dependence of the dissolution enthalpy. Thus values of [29] were not taken into consideration. The data were fitted versus temperature in the given temperature range as:

$$
\Delta_{\mathrm{diss}} H_{\mathrm{Ti}}^{0}=-218.7+0.0589 T\left[\mathrm{~kJ} \mathrm{~mol}^{-1}\right] .
$$

The enthalpies of formation of the intermetallic compounds $\mathrm{Ti}_{0.34} \mathrm{Ni}_{0.18} \mathrm{Al}_{0.48}$ and $\mathrm{Ti}_{0.36} \mathrm{Ni}_{0.24} \mathrm{Al}_{0.40}$ at $298 \mathrm{~K}$ were evaluated using the values of parameters $A=\Delta_{\text {diss }} \bar{H}_{i}^{0}$ from Table 3 as:

$$
\Delta_{298} H^{0}=\sum_{i} n_{i} \Delta_{\text {diss }} \bar{H}_{i}^{0}-\Delta_{\text {diss }} \bar{H}_{\text {COMP }}^{0}
$$

where $\Delta_{\text {diss }} \bar{H}_{i}^{0}$ denotes the first partial enthalpy of dissolution in $\mathrm{Al}$ of one mole of pure substance $i, n_{i}$ is number of moles of a substance $i$ in the intermetallic compound and $\Delta_{\text {diss }} \bar{H}_{\text {COMP }}^{0}$ is the first molar enthalpy of dissolution of the intermetallic compound in aluminium.
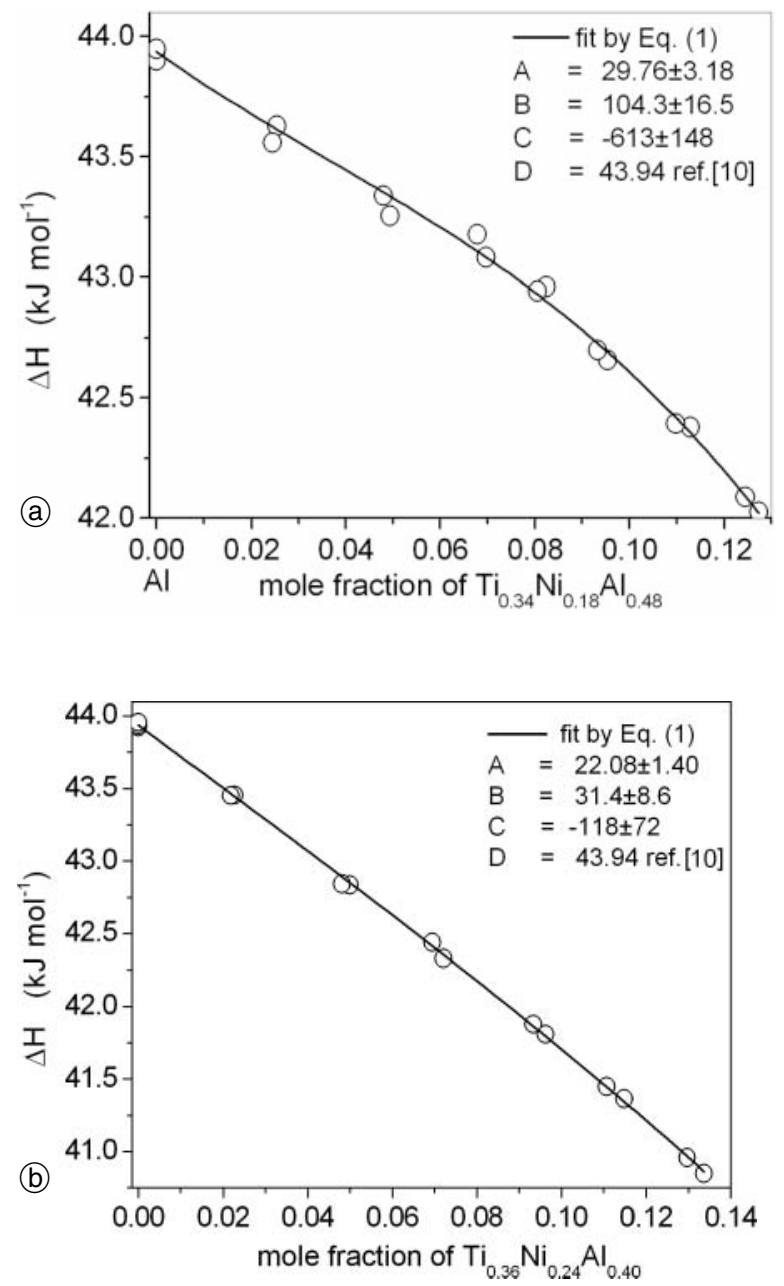

Fig. 7. Integral enthalpy of formation of liquid dilute ternary alloys due to dropping of solid $\mathrm{Al}$ and $\mathrm{Ti}_{0.34} \mathrm{Ni}_{0.18} \mathrm{Al}_{0.48}$ (a), and $\mathrm{Al}$ and $\mathrm{Ti}_{0.36} \mathrm{Ni}_{0.24} \mathrm{Al}_{0.40}$ (b) at $298 \mathrm{~K}$ into liquid $\mathrm{Al}$ at $1409 \pm 5 \mathrm{~K}$ : points are experimental data; lines result from fitting to Eq. (1).

The standard error $(2 \sigma)$ of the enthalpy of formation of the intermetallics was evaluated as:

$$
2 \sigma=\sqrt{\sum_{i}\left(n_{i} E_{i}\right)^{2}+E_{\mathrm{COMP}}^{2}}
$$

where $E_{i}$ and $E_{\mathrm{COMP}}$ denote the $2 \sigma$ error for the $\Delta_{\text {diss }} \bar{H}_{i}^{0}$ and $\Delta_{\text {diss }} \bar{H}_{\text {COMP }}^{0}$, respectively.

Table 3. Values of fitting parameter $\left(\mathrm{kJ} \mathrm{mol}^{-1}\right) A$ of Eq. (1) (A is equal to partial enthalpy of dissolution in pure $\mathrm{Al}$ at infinite dilution, $\Delta_{\text {diss }} \bar{H}_{i}^{0}$ ).

\begin{tabular}{lcl}
\hline Sample & $A \equiv \Delta_{\text {diss }} \bar{H}_{i}^{0}$ & Reference \\
\hline $\mathrm{Al}$ & 43.94 & {$[10]$} \\
$\mathrm{Ni}$ & $-99.80 \pm 3.90$ & this work $^{b}$ \\
$\mathrm{Ti}$ & $-88.87 \pm 6.41$ & {$[9]$} \\
$\mathrm{Ti}$ & $-91.98 \pm 4.26$ & this work \\
$\mathrm{Ti}_{0.34} \mathrm{Ni}_{0.18} \mathrm{Al}_{0.48}$ & $29.76 \pm 3.18$ & this work \\
$\mathrm{Ti}_{0.36} \mathrm{Ni}_{0.24} \mathrm{Al}_{0.40}$ & $22.08 \pm 2.83$ & this work \\
\hline
\end{tabular}

a: Error of $\mathrm{A}( \pm 2 \sigma)$

b: $\mathrm{Al}_{2} \mathrm{O}_{3}$ crucible 
Table 4. Standard enthalpy of formation $\left(\mathrm{kJ} \mathrm{mol}^{-1}\right)$ of the intermetallic compounds referred to $298.15 \mathrm{~K}$.

\begin{tabular}{lll}
\hline Compound & $\Delta_{298} H^{0}$ & Reference \\
\hline $\mathrm{Ni}_{0.5} \mathrm{Al}_{0.5}$ & $-66.1 \pm 1.3^{a}$ & {$[39]$} \\
$\mathrm{Ti}_{0.34} \mathrm{Ni}_{0.18} \mathrm{Al}_{0.48}$ & $-57.9 \pm 3.5^{a}$ & this work \\
$\mathrm{Ti}_{0.36} \mathrm{Ni}_{0.24} \mathrm{Al}_{0.40}$ & $-61.6 \pm 3.3^{a}$ & this work \\
\hline
\end{tabular}

a: Error of $\Delta_{298} H^{0}( \pm 2 \sigma)$

The results of evaluation are summarized in Table 4. For convenience comparison is made between the enthalpy of formation of $\mathrm{NiAl}$ according to [39] and the results obtained for the ternary Laves phases $\mathrm{Ti}_{0.34} \mathrm{Ni}_{0.18} \mathrm{Al}_{0.48}$ and $\mathrm{Ti}_{0.36} \mathrm{Ni}_{0.24} \mathrm{Al}_{0.40}$.

\section{Ground state energies from ab-initio calculations}

\section{Models and $a b$-initio calculations}

Two different ways were considered to systematically investigate the ground state energies for the ternary $\mathrm{Ti}-\mathrm{Ni}-\mathrm{Al}$ Laves phase alloys. (1) Supercells were constructed (see open circles in Fig. 8) on basis of the X-ray single crystal and neutron powder diffraction data on lattice parameters and atom positions. It is prohibitive to simulate precisely the experimental compositions because very large supercells and vast ab-initio calculation time would be needed. We built supercells $(2 a, 2 b, 2 c)$ with 96 atoms as close as possible to the four experimentally investigated compositions (see open squares in Fig. 8): (A) $\mathrm{Ti}_{32 / 96} \mathrm{Ni}_{16 / 96} \mathrm{Al}_{48 / 96}\left(=\mathrm{Ti}_{0.333} \mathrm{Ni}_{0.167} \mathrm{Al}_{0.500}\right)$ in which at $2 a$ sites there are 16 atoms $(8 \mathrm{Al}+8 \mathrm{Ni})$, at $6 h$ sites 48 atoms $(40 \mathrm{Al}+8 \mathrm{Ni})$, and at $4 f$ sites $32 \mathrm{Ti}$ atoms; (B) $\mathrm{Ti}_{34 / 96} \mathrm{Ni}_{24 / 96} \mathrm{Al}_{38 / 96} \quad\left(=\mathrm{Ti}_{0.354} \mathrm{Ni}_{0.25} \mathrm{Al}_{0.395}\right)$ in which at $2 a$ sites there are 16 atoms $(8 \mathrm{Al}+8 \mathrm{Ni})$, at $6 h$ sites 48 atoms $(30 \mathrm{Al}+16 \mathrm{Ni}+2 \mathrm{Ti})$, and at $4 f$ sites $32 \mathrm{Ti}$ atoms. For the Ti-rich composition, $\mathrm{Ti}_{38 / 96} \mathrm{Ni}_{26 / 96} \mathrm{Al}_{32 / 96}$ $\left(=\mathrm{Ti}_{0.395} \mathrm{Ni}_{0.271} \mathrm{Al}_{0.333}\right)$ two possible occupations were considered: (C.1) 16 atoms at $2 a$ sites $(1 \mathrm{Ti}+7 \mathrm{Ni}+8 \mathrm{Al})$

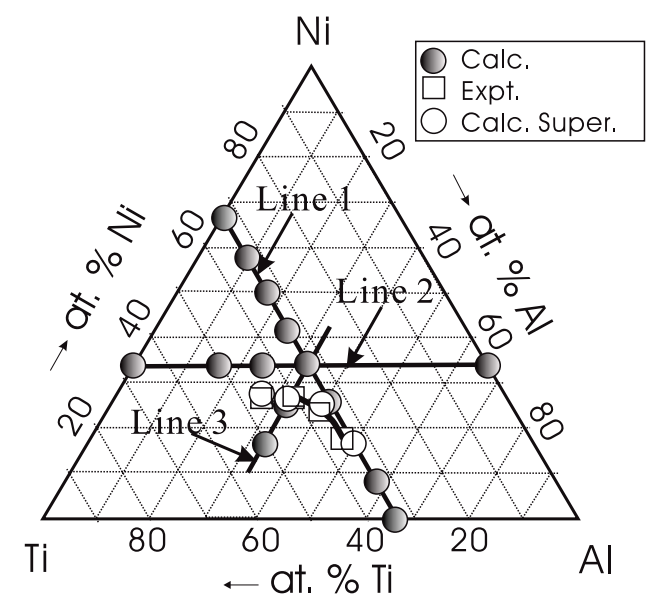

Fig. 8. Compositions investigated by ab-initio calculations for the $\mathrm{MgZn}_{2}$-type (C14) unit cell (grey solid circles). Line 1, Line 2, and Line 3 denote the fixed compositions of 33.3 at $\% \mathrm{Ti}, 33.3 \mathrm{at} \% \mathrm{Ni}$, and 33.3 at $\% \mathrm{Al}$. Open squares mark the composition of the studied experimental samples; open circles denote compositions of 96-atom supercells. Further details, see text. and at $6 h$ sites 48 atoms $(5 \mathrm{Ti}+19 \mathrm{Ni}+24 \mathrm{Al})$ and at $4 f$ sites $32 \mathrm{Ti}$ atoms; (C.2) 16 atoms at $2 a$ sites $(8 \mathrm{Ni}+8 \mathrm{Al})$ and at $6 h$ sites 48 atoms $(6 \mathrm{Ti}+18 \mathrm{Ni}+24 \mathrm{Al})$ and at $4 f$ sites $32 \mathrm{Ti}$ atoms. For composition $\mathrm{Ti}_{42 / 96} \mathrm{Ni}_{26 / 96} \mathrm{Al}_{28 / 96}$ $\left(=\mathrm{Ti}_{0.438} \mathrm{Ni}_{0.26} \mathrm{Al}_{0.292}\right)$ again two possible configurations were considered: (D.1) 16 atoms $(6 \mathrm{Al}+7 \mathrm{Ni}+3 \mathrm{Ti})$ at $2 a$ sites, 48 atoms $(22 \mathrm{Al}+19 \mathrm{Ni}+7 \mathrm{Ti})$ at $6 h$ sites and $32 \mathrm{Ti}$ atoms at $4 f$ sites; (D.2) 16 atoms $(9 \mathrm{Al}+7 \mathrm{Ni})$ at $2 a$ site, 48 atoms $(19 \mathrm{Al}+19 \mathrm{Ni}+10 \mathrm{Ti})$ at $6 h$ sites and $32 \mathrm{Ti}$ atoms at $4 f$ sites. Keeping the experimental lattice parameters fixed and choosing a $3 \times 3 \times 3 k$-mesh, the atomic positions were relaxed.

(2) A series of models within the $\mathrm{MgZn}_{2}$-type unit cell (12 atoms) were built in order to investigate the variation of enthalpies of formation of the pseudobinary $\mathrm{Ti}_{1 / 3}(\mathrm{Ti}, \mathrm{Ni}, \mathrm{Al})_{2 / 3}$ compounds including full relaxation (shape of unit cell, atomic position, and ionic forces as well as atomic distances).

(i) For the (Ni,Al)-rich side, nine compositions were determined with linearly increasing $\mathrm{Al}$ concentration from $\mathrm{Ti}_{1 / 3} \mathrm{Ni}_{2 / 3}$ to $\mathrm{Ti}_{1 / 3} \mathrm{Al}_{2 / 3}$ keeping constant 33.3 at\%-Ti content, shown as Line 1 in Fig. 8: $\mathrm{Ti}_{1 / 3}\left(\mathrm{Ni}_{2 / 3-x / 3} \mathrm{Al}_{x / 3}\right)$ ( $x$ from 0 to 2 in step of 0.25 ).

(ii) For the Ti-rich side, four compositions were considered $\mathrm{Ti}_{1 / 3}\left(\mathrm{Ni}_{1 / 3} \mathrm{Al}_{x / 12} \mathrm{Ti}_{1 / 3-x / 12}\right)(x=0,2,3,4)$, with increasing $\mathrm{Ti}$ concentration from $\mathrm{Ti}_{1 / 3}\left(\mathrm{Ni}_{1 / 3} \mathrm{Al}_{1 / 3}\right)$ to $\mathrm{Ti}_{1 / 3}\left(\mathrm{Ni}_{1 / 3} \mathrm{Ti}_{1 / 3}\right)$ keeping 33.3 at\%-Ni content fixed, (Line 2 in Fig. 8).

(iii) For the $33.3 \%$-Al phase, we considered two compositions $\mathrm{Ti}_{6 / 12} \mathrm{Ni}_{1 / 6} \mathrm{Al}_{1 / 3}$ and $\mathrm{Ti}_{5 / 12} \mathrm{Ni}_{3 / 12} \mathrm{Al}_{1 / 3}$, shown as Line 3 in Fig. 8.

Some simplifications are made: the identical atom site in the $\mathrm{MgZn}_{2}$-type unit cell can be occupied either by one type of atom (e.g., Al atom occupies $2 a$ site) or by two types of atoms (e.g., $\mathrm{Al}$ and $\mathrm{Ni}$ at $2 a$ sites). However, cases with three different types of atoms sharing the identical site (e.g., $\mathrm{Al}, \mathrm{Ni}$, and $\mathrm{Ti}$ together share $2 a$ sites), are not considered.

Experiments indicate that Ti-atoms always occupy all $4 f$ sites, therefore we just vary the occupations on $2 a$ and $6 h$ sites. For this purpose, the total energies of various site-occupying configurations, designed as ${ }^{2 a}\left(\mathrm{Al}_{\mathrm{N} 1} \mathrm{Ni}_{\mathrm{N} 2}\right)^{6 h}\left(\mathrm{Al}_{\mathrm{N} 3} \mathrm{Ni}_{\mathrm{N} 4}, \mathrm{Al}_{\mathrm{N} 5} \mathrm{Ni}_{\mathrm{N} 6}\right)^{4 f}\left(\mathrm{Ti}_{4}\right)$ are investigated. In the $\mathrm{MgZn}_{2}$-type unit cell the Wyckoff superscripts indicate the positions in the ordered phase, and $N_{i}(i=1,2,3$, $4,5,6)$ labels the atoms. In the $\mathrm{MgZn}_{2}$-type unit cell the six atoms $(\mathrm{N} 3+\mathrm{N} 4=3, \mathrm{~N} 5+\mathrm{N} 6=3)$ at $6 h$ sites are situated in two " $6 h$ " planes (plane one: $\mathrm{Al}_{\mathrm{N} 3} \mathrm{Ni}_{\mathrm{N} 4}$, plane two: $\mathrm{Al}_{\mathrm{N} 5} \mathrm{Ni}_{\mathrm{N} 6}$ ), which are identified by the compact expression ${ }^{6 h}\left(\mathrm{Al}_{\mathrm{N} 3} \mathrm{Ni}_{\mathrm{N} 4}, \mathrm{Al}_{\mathrm{N} 5} \mathrm{Ni}_{\mathrm{N} 6}\right)$. According to the symmetry of the $\mathrm{MgZn}_{2}$-type structure, inequivalent arrangements (or decorations) of the atomic sites occur for each composition. In fact, it is much more complex to look for the appropriate decorations in Ti-rich compositions than for the (Ni,Al)-rich compound due to the fact that $\mathrm{Ti}$ atoms not only fully occupy the $4 f$ sites but also possibly occupy the $2 a$ or $6 h$ sites.

Because each of these decorations implies different interplanar and intraplanar atomic interactions, it is necessary to calculate the total energy of each of these to determine the structure to optimize the positions and shapes. For $\mathrm{Ti}_{x} \mathrm{Ni}_{y} \mathrm{Al}_{z}$, the enthalpies of formation are then derived 
from

$$
\Delta H=\frac{1}{x+y+z}\left[E_{\mathrm{Ti}_{x} \mathrm{Ni}_{y} \mathrm{Al}_{z}}^{\mathrm{total}}-x E_{\mathrm{Ti}}^{\mathrm{solid}}-y E_{\mathrm{Ni}}^{\mathrm{solid}}-z E_{\mathrm{Al}}^{\mathrm{solid}}\right]
$$

where $E_{\mathrm{Ti}_{x} \mathrm{Ni}_{y} \mathrm{Al} l_{z}}^{\mathrm{total}}$ denotes the equilibrium total energy of $\mathrm{Ti}_{x} \mathrm{Ni}_{y} \mathrm{Al}_{z}$ and $E_{\mathrm{Ti}}^{\text {solid }}, E_{\mathrm{Ni}}^{\text {solid }}, E_{\mathrm{Al}}^{\text {solid }}$ are the energies of the equilibrium ground states for pure $h c p-\mathrm{Ti}, f c c-\mathrm{Al}$, and $f c c$ ferromagnetic $\mathrm{Ni}$, respectively.

\section{$\mathrm{Ti}_{1 / 3}\left(\mathrm{Ni}_{2 / 3-x / 3} \mathbf{A l} \mathbf{l}_{x / 3}\right)$ Laves phase}

For varying $x$ (0 to 2.0 in step of 0.25 ) presented results are in Table 5 which shows that for each composition several values for enthalpies of formation might be obtained. For the two hypothetical boundary compounds $\mathrm{Ti}_{1 / 3} \mathrm{Ni}_{2 / 3}$ and $\mathrm{Ti}_{1 / 3} \mathrm{Al}_{2 / 3}$ the occupation is unique: $\mathrm{Ti}$ at the $4 f$ sites, and $\mathrm{Ni}$ (or $\mathrm{Al}$ ) at both the $2 a$ and $6 h$ sites. Table 5 shows that with increasing $\mathrm{Al}$ concentrations $\mathrm{Al}$ replaces firstly $\mathrm{Ni}$ at the $2 a$ sites, and then replaces $\mathrm{Ni}$ at the $6 h$ sites. However, Ni substitution behaves in a quite different way. In the case of $\mathrm{Ti}_{1 / 3} \mathrm{Ni}_{1 / 12} \mathrm{Al}_{7 / 12}$ (decorations 20 and 21 in Table 5), one $\mathrm{Ni}$ atom substitutes $\mathrm{Al}$ at the $6 h$ site. With increasing concentration of $\mathrm{Ni}$, for $\mathrm{Ti}_{1 / 3} \mathrm{Ni}_{2 / 12} \mathrm{Al}_{6 / 12}$ (decorations from 17 to 19 in Table 5) two $\mathrm{Ni}$ atoms sit at the $6 h$ sites according to the most stable decoration 18 $\left({ }^{2 a}\left(\mathrm{Al}_{2}\right)^{6 h}\left(\mathrm{Al}_{2} \mathrm{Ni}_{1}, \mathrm{Al}_{2} \mathrm{Ni}_{1}\right)^{4 f}\left(\mathrm{Ti}_{4}\right)\right)$. This indicates that two $\mathrm{Ni}$ atoms are distributed in the two different " $6 h$ " planes: there are no $\mathrm{Ni}-\mathrm{Ni}$ nearest neighbors. This behavior is much clearer seen for $\mathrm{Ti}_{1 / 3} \mathrm{Ni}_{3 / 12} \mathrm{Al}_{5 / 12}$ (decorations 14, 15, and 16 in Table 5). The energy of decoration 16 $\left({ }^{2 a}\left(\mathrm{Al}_{1} \mathrm{Ni}_{1}\right)^{6 h}\left(\mathrm{Al}_{2} \mathrm{Ni}_{1}, \mathrm{Al}_{2} \mathrm{Ni}_{1}\right)^{4 f}\left(\mathrm{Ti}_{4}\right)\right)$, in which the three $\mathrm{Ni}$ atoms lie in two different " $6 h$ " planes and in the $2 a$ plane, is by far the most stable one. From this result we can explain the experimental finding that the concentration of the $\mathrm{Ni}$ atoms at the $2 a$ sites in $\mathrm{Ti}_{0.34} \mathrm{Ni}_{0.18} \mathrm{Al}_{0.48}$ is only $11 \%$ (see Table 2 ) because the $\mathrm{Ni}$ atom prefers to occupy the $6 h$ sites firstly. However, when the concentration of $\mathrm{Ni}$ exceeds that of $\mathrm{Al}, \mathrm{Ni}$ atom now must occupy a $\mathrm{Ni}-\mathrm{Ni}$ nearest neighbor position (decorations 11, 12, and 13).

Optimized lattice parameters are shown in Table 5 for the compositions $\mathrm{Ti}_{1 / 3}\left(\mathrm{Ni}_{2 / 3-x / 3} \mathrm{Al}_{x / 3}\right)$. The calculated enthalpies of formation of the most stable decorations for each concentration and their respective equilibrium volumes are compiled in Fig. 9 which shows that with increasing $\mathrm{Al}$ content the equilibrium volumes increase in an almost linear way. The most stable case is decoration 11 with composition $\mathrm{Ti}_{1 / 3} \mathrm{Ni}_{1 / 3} \mathrm{Al}_{1 / 3}$. From Fig. 9 the most stable phases can be derived with respect to the boundary phases $\mathrm{Ti}_{1 / 3} \mathrm{Ni}_{2 / 3}$ and $\mathrm{Ti}_{1 / 3} \mathrm{Al}_{2 / 3}$ with the $\mathrm{MgZn}_{2}$-type structure considering the fact that for an ordered compound to be stable relative to a two-phase mixture of phases with different compositions, enthalpies of formation must lie below the line connecting the two competing phases. However, both boundary phases do not crystallize in the $\mathrm{MgZn}_{2}$-type structure. For analyzing the structural relative stability of these two hypotetical compounds, we further calculated the enthalpies of formation $\mathrm{Ti}_{1 / 2} \mathrm{Al}_{1 / 2}(\mathrm{CuAu}-$ type, $\left.\mathrm{L1}_{0}\right), \mathrm{Ti}_{1 / 3} \mathrm{Al}_{2 / 3}\left(\mathrm{MgZn}_{2^{-}}, \mathrm{MgCu}_{2^{-}}\right.$, and $\mathrm{HfGa}_{2}$-type structures), and $\mathrm{Ti}_{1 / 4} \mathrm{Al}_{3 / 4}\left(\mathrm{TiAl}_{3}\right.$-type, $\left.\mathrm{DO}_{22}\right)$ and $\mathrm{Ti}_{1 / 2} \mathrm{Ni}_{1 / 2}$ (TiNi-type, $\left.\mathrm{B}_{19}^{\prime}\right), \mathrm{Ti}_{0.333} \mathrm{Ni}_{0.667}\left(\mathrm{MgZn}_{2}\right.$-type, $\left.\mathrm{C} 14\right)$, and $\mathrm{Ti}_{0.25} \mathrm{Ni}_{0.75}$ ( $\mathrm{TiNi}_{3}$-type, $\left.\mathrm{D0}_{24}\right)$. The calculated results of $-39.9,-39.1,-37.6$ and $-46.7 \mathrm{~kJ}(\mathrm{~mol} \text { of atoms })^{-1}$ for the four compounds $\mathrm{Ti}_{0.5} \mathrm{Al}_{0.5}, \mathrm{Ti}_{0.25} \mathrm{Al}_{0.75}, \mathrm{Ti}_{0.5} \mathrm{Ni}_{0.5}$, and

\begin{tabular}{|c|c|c|c|c|c|}
\hline Formula & No. ${ }^{a}$ & Decorations & $\Delta H$ & $a_{0}$ & $c_{0}$ \\
\hline $\mathrm{Ti}_{1 / 3} \mathrm{Ni}_{2 / 3}$ & 1 & ${ }^{2 a}\left(\mathrm{Ni}_{2}\right)^{6 h}\left(\mathrm{Ni}_{3}, \mathrm{Ni}_{3}\right)^{4 f}\left(\mathrm{Ti}_{4}\right)$ & -37.39 & 0.4747 & 0.7727 \\
\hline \multirow[t]{2}{*}{$\mathrm{Ti}_{1 / 3} \mathrm{Ni}_{7 / 12} \mathrm{Al}_{1 / 12}$} & 2 & ${ }^{2 a}\left(\mathrm{Al}_{1} \mathrm{Ni}_{1}\right)^{6 h}\left(\mathrm{Ni}_{3}, \mathrm{Ni}_{3}\right)^{4 f}\left(\mathrm{Ti}_{4}\right)$ & -43.55 & 0.4806 & 0.7723 \\
\hline & 3 & ${ }^{2 a}\left(\mathrm{Ni}_{2}\right)^{6 h}\left(\mathrm{Al}_{1} \mathrm{Ni}_{2}, \mathrm{Ni}_{3}\right)^{4 f}\left(\mathrm{Ti}_{4}\right)$ & -43.15 & 0.4803 & 0.7813 \\
\hline \multirow[t]{3}{*}{$\mathrm{Ti}_{1 / 3} \mathrm{Ni}_{6 / 12} \mathrm{Al}_{2 / 12}$} & 4 & ${ }^{2 a}\left(\mathrm{Al}_{2}\right)^{6 h}\left(\mathrm{Ni}_{3}, \mathrm{Ni}_{3}\right)^{4 f}\left(\mathrm{Ti}_{4}\right)$ & -49.65 & 0.4883 & 0.7650 \\
\hline & 5 & ${ }^{2 a}\left(\mathrm{Ni}_{2}\right)^{6 h}\left(\mathrm{Al}_{1} \mathrm{Ni}_{2}, \mathrm{Al}_{1} \mathrm{Ni}_{2}\right)^{4 f}\left(\mathrm{Ti}_{4}\right)$ & -49.55 & 0.4829 & 0.7883 \\
\hline & 6 & ${ }^{2 a}\left(\mathrm{Al}_{1} \mathrm{Ni}_{1}\right)^{6 h}\left(\mathrm{Al}_{1} \mathrm{Ni}_{2}, \mathrm{Ni}_{3}\right)^{4 f}\left(\mathrm{Ti}_{4}\right)$ & -47.54 & 0.4840 & 0.7842 \\
\hline \multirow[t]{3}{*}{$\mathrm{Ti}_{1 / 3} \mathrm{Ni}_{5 / 12} \mathrm{Al}_{3 / 12}$} & 7 & ${ }^{2 a}\left(\mathrm{Al}_{2}\right)^{6 h}\left(\mathrm{AlNi}_{2}, \mathrm{Ni}_{3}\right)^{4 f}\left(\mathrm{Ti}_{4}\right)$ & -51.34 & 0.4884 & 0.7859 \\
\hline & 8 & ${ }^{2 a}\left(\mathrm{Ni}_{2}\right)^{6 h}\left(\mathrm{Al}_{3}, \mathrm{Ni}_{3}\right)^{4 f}\left(\mathrm{Ti}_{4}\right)$ & -41.13 & 0.4924 & 0.7829 \\
\hline & 9 & ${ }^{2 a}\left(\mathrm{Al}_{1} \mathrm{Ni}_{1}\right)^{6 h}\left(\mathrm{Al}_{1} \mathrm{Ni}_{2}, \mathrm{Al}_{1} \mathrm{Ni}_{2}\right)^{4 f}\left(\mathrm{Ti}_{4}\right)$ & -51.26 & 0.4867 & 0.7927 \\
\hline \multirow[t]{4}{*}{$\mathrm{Ti}_{1 / 3} \mathrm{Ni}_{4 / 12} \mathrm{Al}_{4 / 12}$} & 10 & ${ }^{2 a}\left(\mathrm{Al}_{2}\right)^{6 h}\left(\mathrm{Al}_{2} \mathrm{Ni}_{1}, \mathrm{Ni}_{3}\right)^{4 f}\left(\mathrm{Ti}_{4}\right)$ & -50.39 & 0.4895 & 0.7968 \\
\hline & 11 & ${ }^{2 a}\left(\mathrm{Al}_{2}\right)^{6 h}\left(\mathrm{Al}_{1} \mathrm{Ni}_{2}, \mathrm{Al}_{1} \mathrm{Ni}_{2}\right)^{4 f}\left(\mathrm{Ti}_{4}\right)$ & -53.35 & 0.4908 & 0.8039 \\
\hline & 12 & ${ }^{2 a}\left(\mathrm{Ni}_{2}\right)^{6 h}\left(\mathrm{Al}_{1} \mathrm{Ni}_{2}, \mathrm{Al}_{1} \mathrm{Ni}_{2}\right)^{4 f}\left(\mathrm{Ti}_{4}\right)$ & -52.26 & 0.4887 & 0.7901 \\
\hline & 13 & ${ }^{2 a}\left(\mathrm{Al}_{1} \mathrm{Ni}_{1}\right)^{6 h}\left(\mathrm{Al}_{3}, \mathrm{Ni}_{3}\right)^{4 f}\left(\mathrm{Ti}_{4}\right)$ & -41.56 & 0.4984 & 0.7897 \\
\hline \multirow[t]{3}{*}{$\mathrm{Ti}_{1 / 3} \mathrm{Ni}_{3 / 12} \mathrm{Al}_{5 / 12}$} & 14 & ${ }^{2 a}\left(\mathrm{Ni}_{2}\right)^{6 h}\left(\mathrm{Al}_{2} \mathrm{Ni}_{1}, \mathrm{Al}_{3}\right)^{4 f}\left(\mathrm{Ti}_{4}\right)$ & -49.85 & 0.5806 & 0.7851 \\
\hline & 15 & ${ }^{2 a}\left(\mathrm{Al}_{2}\right)^{6 h}\left(\mathrm{Al}_{3}, \mathrm{Ni}_{3}\right)^{4 f}\left(\mathrm{Ti}_{4}\right)$ & -41.44 & 0.5021 & 0.8001 \\
\hline & 16 & ${ }^{2 a}\left(\mathrm{Al}_{1} \mathrm{Ni}_{1}\right)^{6 h}\left(\mathrm{Al}_{2} \mathrm{Ni}_{1}, \mathrm{Al}_{2} \mathrm{Ni}_{1}\right)^{4 f}\left(\mathrm{Ti}_{4}\right)$ & -52.72 & 0.5005 & 0.8072 \\
\hline \multirow[t]{3}{*}{$\mathrm{Ti}_{1 / 3} \mathrm{Ni}_{2 / 12} \mathrm{Al}_{6 / 12}$} & 17 & ${ }^{2 a}\left(\mathrm{Ni}_{2}\right)^{6 h}\left(\mathrm{Al}_{3}, \mathrm{Al}_{3}\right)^{4 f}\left(\mathrm{Ti}_{4}\right)$ & -50.76 & 0.5142 & 0.7814 \\
\hline & 18 & ${ }^{2 a}\left(\mathrm{Al}_{2}\right)^{6 h}\left(\mathrm{Al}_{2} \mathrm{Ni}_{1}, \mathrm{Al}_{2} \mathrm{Ni}_{1}\right)^{4 f}\left(\mathrm{Ti}_{4}\right)$ & -50.96 & 0.5047 & 0.8209 \\
\hline & 19 & ${ }^{2 a}\left(\mathrm{Al}_{1} \mathrm{Ni}_{1}\right)^{6 h}\left(\mathrm{Al}_{2} \mathrm{Ni}_{1}, \mathrm{Al}_{3}\right)^{4 f}\left(\mathrm{Ti}_{4}\right)$ & -46.65 & 0.5127 & 0.8058 \\
\hline \multirow[t]{2}{*}{$\mathrm{Ti}_{1 / 3} \mathrm{Ni}_{1 / 12} \mathrm{Al}_{7 / 12}$} & 20 & ${ }^{2 a}\left(\mathrm{Al}_{2}\right)^{6 h}\left(\mathrm{Ni}_{1} \mathrm{Al}_{2}, \mathrm{Al}_{3}\right)^{4 f}\left(\mathrm{Ti}_{4}\right)$ & -44.58 & 0.5195 & 0.8064 \\
\hline & 21 & ${ }^{2 a}\left(\mathrm{Al}_{1} \mathrm{Ni}_{1}\right)^{6 h}\left(\mathrm{Al}_{3}, \mathrm{Al}_{3}\right)^{4 f}\left(\mathrm{Ti}_{4}\right)$ & -43.46 & 0.5150 & 0.8288 \\
\hline $\mathrm{Ti}_{1 / 3} \mathrm{Al}_{8 / 12}$ & 22 & ${ }^{2 a}\left(\mathrm{Al}_{2}\right)^{6 h}\left(\mathrm{Al}_{3}, \mathrm{Al}_{3}\right)^{4 f}\left(\mathrm{Ti}_{4}\right)$ & -36.15 & 0.5135 & 0.8407 \\
\hline
\end{tabular}

Table 5. Models, calculated enthalpies of formation $\left(\Delta H, \mathrm{~kJ}(\mathrm{~mol} \text { of atoms })^{-1}\right)$, and lattice parameter $(\mathrm{nm})$ for site perfectly occupied pseudobinary $\mathrm{MgZn}_{2}$-type (C14) Laves-phase compounds $\mathrm{Ti}_{1 / 3}(\mathrm{Al}, \mathrm{Ni})_{2 / 3}$ corresponding to these compounds denoted by the Line 1 in Fig. 8.

a: Bold numbers denote most stable decorations 


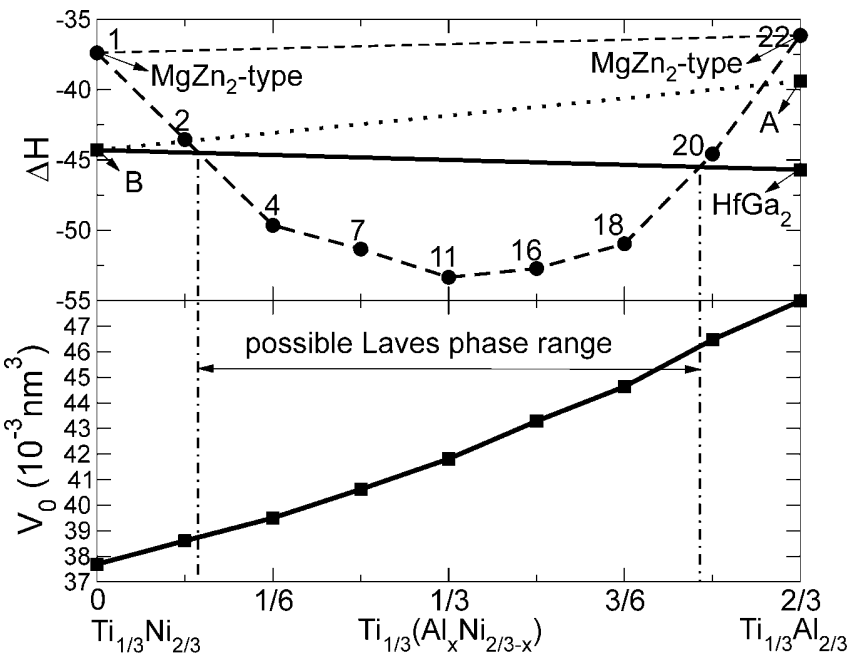

Fig. 9. Calculated enthalpies of formation $\left(\mathrm{kJ}(\mathrm{mol} \text { of atoms })^{-1}\right)$ and the equilibrium volume as the function of $\mathrm{Al}$ contents from $\mathrm{Ti}_{1 / 3} \mathrm{Ni}_{2 / 3}$ to $\mathrm{Ti}_{1 / 3} \mathrm{Al}_{2 / 3}$. The labeled numbers denote the energetically stable sitepreference structures in Table 5. A and B points are from Fig. 10 denoting the critical stable conditions of $\mathrm{Ti}_{1 / 3} \mathrm{Ni}_{2 / 3}$ and $\mathrm{Ti}_{1 / 3} \mathrm{Al}_{2 / 3}$, respectively.

$\mathrm{Ti}_{0.25} \mathrm{Ni}_{0.75}$, respectively, are in very good agreement with previous calculations and experiments [41-60]. The calculated enthalpies of formation as a function of $\mathrm{Al}$ and $\mathrm{Ni}$ concentrations are compared in Fig. 10 where the tie lines from $\mathrm{Ti}_{0.5} \mathrm{Al}_{0.5}$ to $\mathrm{Ti}_{0.25} \mathrm{Al}_{0.75}$ and from $\mathrm{Ti}_{0.5} \mathrm{Ni}_{0.5}$ to $\mathrm{Ti}_{0.25} \mathrm{Ni}_{0.75}$ are shown. The two enthalpies of formation for the hypothetical $\mathrm{MgZn}_{2}$-type $(\mathrm{C} 14)$ and $\mathrm{MgCu}_{2}$-type $(\mathrm{C} 15)$ Laves phases, $\mathrm{Ti}_{1 / 3} \mathrm{Al}_{2 / 3}$ and $\mathrm{Ti}_{1 / 3} \mathrm{Ni}_{2 / 3}$, both lie above the tie lines by 3.3 and $6.4 \mathrm{~kJ}$ (mol of atoms) $)^{-1}$, respectively. Accordingly, from Fig. 10 one finds that for stabilizing the Laves phases $\mathrm{Ti}_{1 / 3} \mathrm{Al}_{2 / 3}$ and $\mathrm{Ti}_{1 / 3} \mathrm{Ni}_{2 / 3}$ the enthalpies of formation must be lower than -39.4 (point A) and -44.3 (point B) $\mathrm{kJ}$ (mol of atoms) ${ }^{-1}$, respectively, see Fig. 9. It also shows that the relative stability of ternary compounds with respect to the stable $\mathrm{Ti}_{1 / 3} \mathrm{Al}_{2 / 3}$ phase (with $\mathrm{HfGa}_{2}$ structure) defines the maximally possible stable range for $\mathrm{Ti}_{1 / 3} \mathrm{Al}_{x} \mathrm{Ni}_{2 / 3-x}(0.10<x<0.57)$. The experimentally synthesized Laves phases, $\mathrm{Ti}_{0.34} \mathrm{Ni}_{0.18} \mathrm{Al}_{0.48}$ and $\mathrm{Ti}_{0.36} \mathrm{Ni}_{0.24} \mathrm{Al}_{0.40}$, are located in this range, confirming our calculations. Furthermore, the prediction for the Al-rich end of the homogeneity region of $x \approx 0.57$ is in good agreement with the experimental phase diagram [1].

The experimentally synthesized compounds $\mathrm{Ti}_{0.34} \mathrm{Ni}_{0.18} \mathrm{Al}_{0.48}$ and $\mathrm{Ti}_{0.36} \mathrm{Ni}_{0.24} \mathrm{Al}_{0.40}$ are in the modeling range between $\mathrm{Ti}_{1 / 3} \mathrm{Ni}_{1 / 3} \mathrm{Al}_{1 / 3}$ and $\mathrm{Ti}_{1 / 3} \mathrm{Ni}_{2 / 12} \mathrm{Al}_{6 / 12}$. By linear interpolation of the enthalpies of formation between $\mathrm{Ti}_{0.333} \mathrm{Ni}_{0.187} \mathrm{Al}_{0.48}$ and $\mathrm{Ti}_{0.333} \mathrm{Ni}_{0.267} \mathrm{Al}_{0.40}$ (which are as

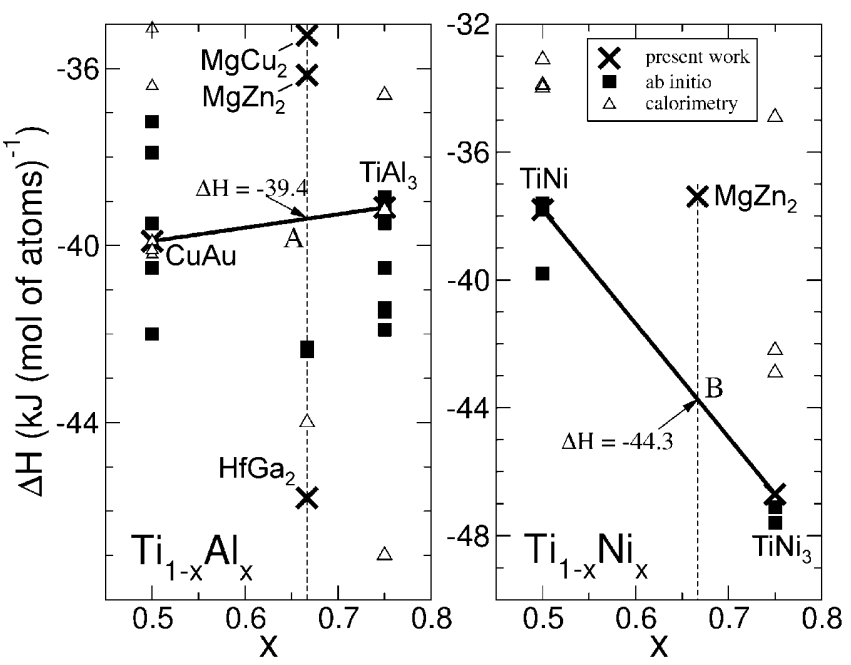

Fig. 10. Formation energies of $\mathrm{Ti}_{1-x} \mathrm{Al}_{x}$ and $\mathrm{Ti}_{1-x} \mathrm{Ni}_{x}$ as compared to previous $a b$-initio calculations and calorimetric data, see text. The solid lines connect the stable phases of the present work.

close as possible to the existing experimental phases) the values of -51.3 and $-52.2 \mathrm{~kJ}$ (mol of atoms) $)^{-1}$ are derived as shown in Table 6 . By another procedure calculating the 96-atoms supercells for $\mathrm{Ti}_{0.333} \mathrm{Ni}_{0.167} \mathrm{Al}_{0.500}$ and $\mathrm{Ti}_{0.354} \mathrm{Ni}_{0.25} \mathrm{Al}_{0.395}$ their corresponding enthalpies of formation are obtained which are -49.4 and $-50.1 \mathrm{~kJ}$ (mol of atoms $)^{-1}$. Table 6 lists these values together with the interpolated results, which are more stable by about $2 \mathrm{~kJ}$ (mole of atoms $)^{-1}$ mainly due to the effect of the structural relaxation. Comparing to the experimental results, the interpolated values are closer to the more negative experimental data $\left(\Delta H^{0}=-57.9 \pm 3.5\right.$ for $x_{\mathrm{Al}}=0.48 ; \Delta H^{0}=$ $-61.6 \pm 3.3$ for $x_{\mathrm{Al}}=0.40 \mathrm{~kJ}(\mathrm{~mol} \text { of atoms })^{-1}$ ). The significant deviations about 6.6 and $9.4 \mathrm{~kJ}$ (mol of atoms) ${ }^{-1}$ may be attributed to temperature effect: our calculations refer to $T=0 \mathrm{~K}$ whereas the experiments refer to $298 \mathrm{~K}$. Furthermore, with our chosen cells we could not exactly model the phases with the experimental compositions. However, for the stoichiometric compounds our ab-initio approach usually obtains very good agreement to experiments, e.g., for NiAl (CsCl-type, B2) we derived the value for the enthalpy of formation of $-64.2 \mathrm{~kJ}$ (mole of atoms $)^{-1}$, in very good agreement with the latest experimental value of $-66.1 \pm 1.3 \mathrm{~kJ}$ (mole of atoms) ${ }^{-1}$ [39] as well as the latest ab-initio data of $-63.4 \mathrm{~kJ}$ (mole of atoms $)^{-1}$ [41]. We also refer to the discussion of boundary phases made previously. Finally, our ab inito approach was also successful for a variety of Laves phase compounds [9, 61-63].

Table 6. Standard enthalpy of formation $\left(\Delta H, \mathrm{~kJ}\right.$ (mol of atoms) $\left.{ }^{-1}\right)$ of the Laves phases referred to $298.15 \mathrm{~K}$ and comparison with the ab-initio ground state energies at $0 \mathrm{~K}$.

\begin{tabular}{|c|c|c|c|c|}
\hline Method (K) & A & B & C. $1 /$ C. 2 & D.1/D.2 \\
\hline$A b$-initio, supercell, fixed & $\begin{array}{l}-49.4 \\
\mathrm{Ti}_{0.333} \mathrm{Ni}_{0.167} \mathrm{Al}_{0.500}\end{array}$ & $\begin{array}{l}-50.1 \\
\mathrm{Ti}_{0.354} \mathrm{Ni}_{0.25} \mathrm{Al}_{0.395}\end{array}$ & $\begin{array}{l}-46.1 /-44.6 \\
\mathrm{Ti}_{0.395} \mathrm{Ni}_{0.27} \mathrm{Al}_{0.333}\end{array}$ & $\begin{array}{l}-42.5 /-40.8 \\
\mathrm{Ti}_{0.438} \mathrm{Ni}_{0.26} \mathrm{Al}_{0.292}\end{array}$ \\
\hline Interpolation estimation from $a b$-initio & $\begin{array}{l}-51.3 \\
\mathrm{Ti}_{0.333} \mathrm{Ni}_{0.187} \mathrm{Al}_{0.48}\end{array}$ & $\begin{array}{l}-52.2 \\
\operatorname{Ti}_{0.333} \mathrm{Ni}_{0.267} \mathrm{Al}_{0.40}\end{array}$ & $\begin{array}{l}-49.7 \\
\mathrm{Ti}_{0.395} \mathrm{Ni}_{0.27} \mathrm{Al}_{0.333}\end{array}$ & $\begin{array}{l}-47.1, \\
\mathrm{Ti}_{0.438} \mathrm{Ni}_{0.26} \mathrm{Al}_{0.292}\end{array}$ \\
\hline Calorimetry & $\begin{array}{l}-57.9 \pm 3.5 \\
\mathrm{Ti}_{0.34} \mathrm{Ni}_{0.18} \mathrm{Al}_{0.48}\end{array}$ & $\begin{array}{l}-61.6 \pm 3.3 \\
\mathrm{Ti}_{0.36} \mathrm{Ni}_{0.24} \mathrm{Al}_{0.40}\end{array}$ & - & - \\
\hline
\end{tabular}




\begin{tabular}{|c|c|c|c|c|c|}
\hline Formula & No. & Decorations & $\Delta H$ & $a_{0}$ & $c_{0}$ \\
\hline \multirow[t]{2}{*}{$\mathrm{Ti}_{2 / 3} \mathrm{Ni}_{1 / 3}$} & 1 & ${ }^{2 a}\left(\mathrm{Ni}_{2}\right)^{6 h}\left(\mathrm{Ti}_{2} \mathrm{Ni}_{2} \mathrm{Ti}_{2} \mathrm{Ni}^{4}\right)^{4 f}\left(\mathrm{Ti}_{4}\right)$ & -25.8 & 0.4956 & 0.7996 \\
\hline & 2 & ${ }^{2 a}\left(\mathrm{Ti}_{2}\right)^{6 h}\left(\mathrm{Ti}_{3}, \mathrm{Ti}_{3}\right)^{4 f}\left(\mathrm{Ni}_{4}\right)$ & 23.0 & 0.4866 & 0.8654 \\
\hline \multirow[t]{15}{*}{$\mathrm{Ti}_{6 / 12} \mathrm{Ni}_{1 / 3} \mathrm{Al}_{2 / 12}$} & 3 & ${ }^{2 a}\left(\mathrm{Al}_{2}\right)^{6 h}\left(\mathrm{Ti}_{1} \mathrm{Ni}_{2}, \mathrm{Ti}_{1} \mathrm{Ni}_{2}\right)^{4 f}\left(\mathrm{Ti}_{4}\right)$ & -41.6 & 0.4960 & 0.8106 \\
\hline & 4 & ${ }^{2 a}\left(\mathrm{Al}_{2}\right)^{6 h}\left(\mathrm{Ti}_{2} \mathrm{Ni}_{1}, \mathrm{Ni}_{3}\right)^{4 f}\left(\mathrm{Ti}_{4}\right)$ & -37.2 & 0.4936 & 0.8084 \\
\hline & 5 & ${ }^{2 a}\left(\mathrm{Ti}_{2}\right)^{6 h}\left(\mathrm{Al}_{1} \mathrm{Ni}_{2}, \mathrm{Al}_{1} \mathrm{Ni}_{2}\right)^{4 f}\left(\mathrm{Ti}_{4}\right)$ & -39.6 & 0.4907 & 0.8039 \\
\hline & 6 & ${ }^{2 a}\left(\mathrm{Ti}_{2}\right)^{6 h}\left(\mathrm{Al}_{2} \mathrm{Ni}_{1}, \mathrm{Ni}_{3}\right)^{4 f}\left(\mathrm{Ti}_{4}\right)$ & -37.8 & 0.4946 & 0.8070 \\
\hline & 7 & ${ }^{2 a}\left(\mathrm{Ni}_{2}\right)^{6 h}\left(\mathrm{Al}_{1} \mathrm{Ti}_{1} \mathrm{Ni}_{1}, \mathrm{Al}_{1} \mathrm{Ti}_{1} \mathrm{Ni}_{1}\right)^{4 f}\left(\mathrm{Ti}_{4}\right)$ & -39.8 & 0.5135 & 0.7865 \\
\hline & 8 & ${ }^{2 a}\left(\mathrm{Ni}_{2}\right)^{6 h}\left(\mathrm{Ti}_{1} \mathrm{Ni}_{2}, \mathrm{Al}_{2} \mathrm{Ti}_{1}\right)^{4 f}\left(\mathrm{Ti}_{4}\right)$ & -43.1 & 0.4922 & 0.8195 \\
\hline & 9 & ${ }^{2 a}\left(\mathrm{Ni}_{2}\right)^{6 h}\left(\mathrm{Al}_{2} \mathrm{Ti}_{1}, \mathrm{Ti}_{1} \mathrm{Ni}_{2}\right)^{4 f}\left(\mathrm{Ti}_{4}\right)$ & -32.3 & 0.5115 & 0.7825 \\
\hline & 10 & ${ }^{2 a}\left(\mathrm{Ti}_{1} \mathrm{Al}_{1}\right)^{6 h}\left(\mathrm{Ti}_{1} \mathrm{Al}_{1} \mathrm{Ni}_{1}, \mathrm{Ni}_{3}\right)^{4 f}\left(\mathrm{Ti}_{4}\right)$ & -36.2 & 0.4964 & 0.7998 \\
\hline & 11 & ${ }^{2 a}\left(\mathrm{Ti}_{1} \mathrm{Al}_{1}\right)^{6 h}\left(\mathrm{Ti}_{1} \mathrm{Ni}_{2}, \mathrm{Al}_{1} \mathrm{Ni}_{2}\right)^{4 f}\left(\mathrm{Ti}_{4}\right)$ & -41.7 & 0.4944 & 0.8169 \\
\hline & 12 & ${ }^{2 a}\left(\mathrm{Ti}_{1} \mathrm{Ni}_{1}\right)^{6 h}\left(\mathrm{Ni}_{3}, \mathrm{Al}_{2} \mathrm{Ti}_{1}\right)^{4 f}\left(\mathrm{Ti}_{4}\right)$ & -28.0 & 0.5090 & 0.7877 \\
\hline & 13 & ${ }^{2 a}\left(\mathrm{Ti}_{1} \mathrm{Ni}_{1}\right)^{6 h}\left(\mathrm{Al}_{1} \mathrm{Ni}_{2}, \mathrm{Ti}_{1} \mathrm{Al}_{1} \mathrm{Ni}_{1}\right)^{4 f}\left(\mathrm{Ti}_{4}\right)$ & -36.7 & 0.4940 & 0.8040 \\
\hline & 14 & ${ }^{2 a}\left(\mathrm{Ti}_{1} \mathrm{Ni}_{1}\right)^{6 h}\left(\mathrm{Al}_{2} \mathrm{Ni}_{1}, \mathrm{Ti}_{1} \mathrm{Ni}_{2}\right)^{4 f}\left(\mathrm{Ti}_{4}\right)$ & -38.8 & 0.4921 & 0.8116 \\
\hline & 15 & ${ }^{2 a}\left(\mathrm{Al}_{1} \mathrm{Ni}_{1}\right)^{6 h}\left(\mathrm{Ti}_{1} \mathrm{Ni}_{2}, \mathrm{Ti}_{1} \mathrm{Al}_{1} \mathrm{Ni}_{1}\right)^{4 f}\left(\mathrm{Ti}_{4}\right)$ & -38.0 & 0.5124 & 0.8055 \\
\hline & 16 & ${ }^{2 a}\left(\mathrm{Al}_{1} \mathrm{Ni}_{1}\right)^{6 h}\left(\mathrm{Ti}_{2} \mathrm{Ni}_{1}, \mathrm{Al}_{1} \mathrm{Ni}_{2}\right)^{4 f}\left(\mathrm{Ti}_{4}\right)$ & -37.3 & 0.4903 & 0.8172 \\
\hline & 17 & ${ }^{2 a}\left(\mathrm{Al}_{1} \mathrm{Ni}_{1}\right)^{6 h}\left(\mathrm{Ti}_{2} \mathrm{Al}_{1}, \mathrm{Ni}_{3}\right)^{4 f}\left(\mathrm{Ti}_{4}\right)$ & -28.7 & 0.5100 & 0.7948 \\
\hline \multirow[t]{11}{*}{$\mathrm{Ti}_{5 / 12} \mathrm{Ni}_{1 / 3} \mathrm{Al}_{3 / 12}$} & 18 & ${ }^{2 a}\left(\mathrm{Ti}_{1} \mathrm{Al}_{1}\right)^{6 h}\left(\mathrm{Al}_{2} \mathrm{Ni}_{1}, \mathrm{Ni}_{3}\right)^{4 f}\left(\mathrm{Ti}_{4}\right)$ & -43.6 & 0.5031 & 0.8050 \\
\hline & 19 & ${ }^{2 a}\left(\mathrm{Ti}_{1} \mathrm{Al}_{1}\right)^{6 h}\left(\mathrm{Al}_{1} \mathrm{Ni}_{2}, \mathrm{Al}_{1} \mathrm{Ni}_{2}\right)^{4 f}\left(\mathrm{Ti}_{4}\right)$ & -46.8 & 0.4925 & 0.8138 \\
\hline & 20 & ${ }^{2 a}\left(\mathrm{Ti}_{1} \mathrm{Ni}_{1}\right)^{6 h}\left(\mathrm{Al}_{3}, \mathrm{Ni}_{3}\right)^{4 f}\left(\mathrm{Ti}_{4}\right)$ & -35.3 & 0.4997 & 0.7988 \\
\hline & 21 & ${ }^{2 a}\left(\mathrm{Ti}_{1} \mathrm{Ni}_{1}\right)^{6 h}\left(\mathrm{Al}_{2} \mathrm{Ni}_{1}, \mathrm{Al}_{1} \mathrm{Ni}_{2}\right)^{4 f}\left(\mathrm{Ti}_{4}\right)$ & -43.8 & 0.4893 & 0.8083 \\
\hline & 22 & ${ }^{2 a}\left(\mathrm{Al}_{2}\right)^{6 h}\left(\mathrm{Ni}_{2} \mathrm{Al}_{1}, \mathrm{Ti}_{1} \mathrm{Ni}_{2}\right)^{4 f}\left(\mathrm{Ti}_{4}\right)$ & -47.2 & 0.4897 & 0.8099 \\
\hline & 23 & ${ }^{2 a}\left(\mathrm{Al}_{2}\right)^{6 h}\left(\mathrm{Ni}_{1} \mathrm{Ti}_{1} \mathrm{Al}_{1}, \mathrm{Ni}_{3}\right)^{4 f}\left(\mathrm{Ti}_{4}\right)$ & -42.6 & 0.5114 & 0.7943 \\
\hline & 24 & ${ }^{2 a}\left(\mathrm{Ni}_{2}\right)^{6 h}\left(\mathrm{Ti}_{1} \mathrm{Al}_{2}, \mathrm{Ni}_{2} \mathrm{Al}_{1}\right)^{4 f}\left(\mathrm{Ti}_{4}\right)$ & -40.2 & 0.5105 & 0.7768 \\
\hline & 25 & ${ }^{2 a}\left(\mathrm{Ni}_{2}\right)^{6 h}\left(\mathrm{Ti}_{1} \mathrm{Ni}_{1} \mathrm{Al}_{1}, \mathrm{Al}_{2} \mathrm{Ni}_{1}\right)^{4 f}\left(\mathrm{Ti}_{4}\right)$ & -44.8 & 0.5097 & 0.7895 \\
\hline & 26 & ${ }^{2 a}\left(\mathrm{Ni}_{2}\right)^{6 h}\left(\mathrm{Ti}_{1} \mathrm{Ni}_{2}, \mathrm{Al}_{3}\right)^{4 f}\left(\mathrm{Ti}_{4}\right)$ & -41.7 & 0.5014 & 0.7903 \\
\hline & 27 & ${ }^{2 a}\left(\mathrm{Al}_{1} \mathrm{Ni}_{1}\right)^{6 h}\left(\mathrm{Ni}_{2} \mathrm{Ti}_{1}, \mathrm{Al}_{2} \mathrm{Ni}_{1}\right)^{4 f}\left(\mathrm{Ti}_{4}\right)$ & -49.0 & 0.4920 & 0.8113 \\
\hline & 28 & ${ }^{2 a}\left(\mathrm{Al}_{1} \mathrm{Ni}_{1}\right)^{6 h}\left(\mathrm{Ti}_{1} \mathrm{Al}_{2}, \mathrm{Ni}_{3}\right)^{4 f}\left(\mathrm{Ti}_{4}\right)$ & -34.9 & 0.5082 & 0.7821 \\
\hline $\mathrm{Ni}_{1 / 3} \mathrm{Al}_{2 / 3}$ & 29 & ${ }^{2 a}\left(\mathrm{Ni}_{2}\right)^{6 h}\left(\mathrm{Al}_{2} \mathrm{Ni}, \mathrm{Al}_{2} \mathrm{Ni}\right)^{4 f}\left(\mathrm{Al}_{4}\right)$ & -40.5 & 0.4783 & 0.7997 \\
\hline
\end{tabular}

Table 7. Models, calculated enthalpies of formation $\left(\Delta H, \mathrm{~kJ}(\mathrm{~mol} \text { of atoms })^{-1}\right)$, and lattice parameter $(\mathrm{nm})$ for site perfectly occupied pseudobinary Laves-phase $\mathrm{Ni}_{1 / 3}(\mathrm{Al}, \mathrm{Ti})_{2 / 3}$ with the $\mathrm{MgZn}_{2}$-type (C14) structure.

a: Bold numbers denote most stable decorations

\section{$\mathrm{Ti}_{1 / 3}\left(\mathrm{Ni}_{1 / 3} \mathrm{Al}_{x} \mathrm{Ti}_{1 / 3-x}\right)$ and $\mathrm{Ti}_{1 / 3}\left(\mathrm{Al}_{1 / 3} \mathrm{Ni}_{x} \mathrm{Ti}_{1 / 3-x}\right)$ Laves phase}

Ti-rich ternary Laves phase compounds are investigated according to Line 2 shown in Fig. 8. By the calculations, we derived the enthalpies of formation and lattice parameters for each possible decoration given in Table 7. In order to test whether $\mathrm{Ti}$ atoms in the $>33.3$ at\% Ti cases fully occupy the $4 f$ site, we first make comparative studies for the boundary phase $\mathrm{Ni}_{1 / 3} \mathrm{Ti}_{2 / 3}$ assuming two decorations: (i) ${ }^{2 a}\left(\mathrm{Ni}_{2}\right)^{6 h}\left(\mathrm{Ti}_{2} \mathrm{Ni}, \mathrm{Ti}_{2} \mathrm{Ni}\right)^{4 f}\left(\mathrm{Ti}_{4}\right)-\mathrm{Ti}$ occupies the $4 f$ and $6 h$ sites, and (ii) ${ }^{2 a}\left(\mathrm{Ti}_{2}\right)^{6 h}\left(\mathrm{Ti}_{3}, \mathrm{Ti}_{3}\right)^{4 f}\left(\mathrm{Ni}_{4}\right)-\mathrm{Ti}$ locates in the $2 a$ and $6 h$ sites. For the latter the calculated enthalpy of formation is considerably positive (instable) but the former has a negative value of $-25.8 \mathrm{~kJ}$ (mol of atoms) ${ }^{-1}$, being energetically much more stable by about $50 \mathrm{~kJ}$ than the latter. Therefore, $\mathrm{Ni}$ avoids the $4 f$ sites but $\mathrm{Ti}$ prefers the $4 f$ and $6 h$ sites. Table 7 shows 15 and $11 \mathrm{dec}-$ orations for 50 at $\%-\mathrm{Ti}$ and 41.7 at $\%$-Ti, respectively. For the 50 at $\%$ - $\mathrm{Ti}$ case $\left(\mathrm{Ni}_{1 / 3} \mathrm{Ti}_{6 / 12} \mathrm{Al}_{2 / 12}\right)$ the decoration $8\left({ }^{2 a}\left(\mathrm{Ni}_{2}\right)^{6 h}\left(\mathrm{Ti}_{1} \mathrm{Ni}_{2}, \mathrm{Ti}_{1} \mathrm{Al}_{2}\right)^{4 f}\left(\mathrm{Ti}_{4}\right)\right)$ is the most stable one $\left.(-43.1 \mathrm{~kJ} \text { (mol of atoms) })^{-1}\right)$, indicating that Ti prefers $4 f$ sites with each of the " $6 h$ " planes containing one Ti. Ni pairs in $6 h$ and $2 a$ sites because in this case Ni concentrations ex- ceed that of $\mathrm{Al}$ as according to the already discussed results for (Ni,Al)-rich phases with fixed 33.3 at\% Ti content. For the 41.7 at $\%$ - $\mathrm{Ti}$ case $\left(\mathrm{Ni}_{1 / 3} \mathrm{Ti}_{5 / 12} \mathrm{Al}_{3 / 12}\right)$ decoration 27

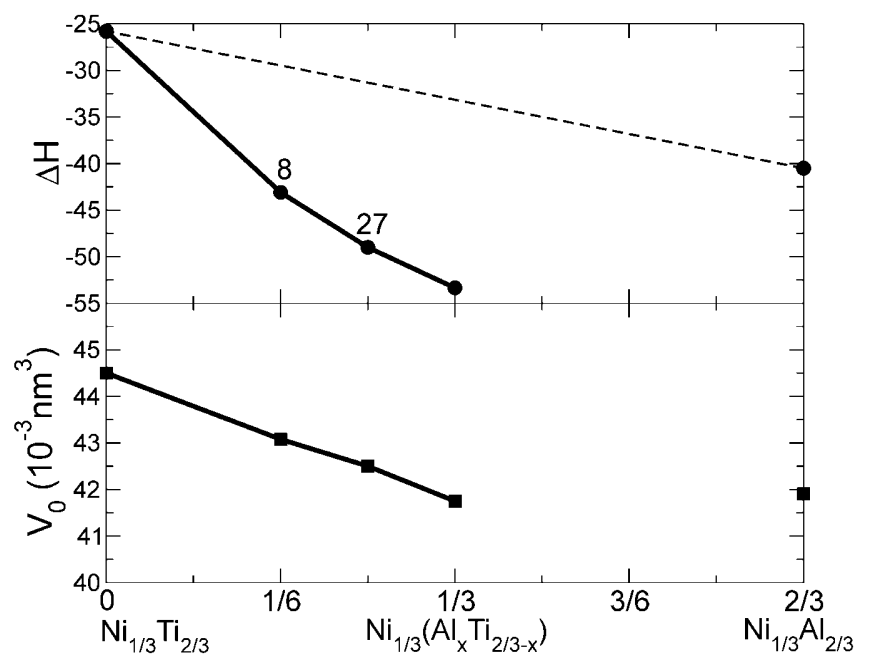

Fig. 11. Calculated enthalpies of formation $\left(\mathrm{kJ}(\mathrm{mol} \text { of atoms })^{-1}\right)$ and the equilibrium volume as a function of $\mathrm{Al}$ contents. The numbers denote the most stable decoration as given in Table 7, the value for $\mathrm{Ti}_{1 / 3} \mathrm{Ni}_{1 / 3} \mathrm{Al}_{1 / 3}$ refers to Table 5 . 
$\left({ }^{2 a}\left(\mathrm{Al}_{1} \mathrm{Ni}_{1}\right)^{6 h}\left(\mathrm{Ni}_{2} \mathrm{Ti}_{1}, \mathrm{Al}_{2} \mathrm{Ni}_{1}\right)^{4 f}\left(\mathrm{Ti}_{4}\right)\right)$ is the most stable one in which $\mathrm{Al}$ and $\mathrm{Ni}$ equivalently share $2 a$ sites, and two $\mathrm{Ni}$ and one Ti occupy one " $6 h$ " plane and two $\mathrm{Al}$ and one Ni lie in the other " $6 h$ " plane. This shows a basic trend of atom occupation that with decreasing $\mathrm{Ti}$ concentration from $\mathrm{Ni}_{1 / 3} \mathrm{Ti}_{2 / 3}$ to $\mathrm{Ni}_{1 / 3} \mathrm{Ti}_{1 / 3} \mathrm{Al}_{1 / 3}$, first the $2 a$ sites are filled by $\mathrm{Ni}$, and with increasing $\mathrm{Al}$ concentration $\mathrm{Ni}$ and $\mathrm{Al}$ share $2 a$ sites before Al fully occupies them (decoration 11 in Table 5).

The enthalpies of formation and equilibrium volume for the most stable decorations for each concentration are compiled in Fig. 11 from which one sees that the equilibrium volume decreases with decreasing $\mathrm{Ti}$ content from $\mathrm{Ni}_{1 / 3} \mathrm{Ti}_{2 / 3}$ to $\mathrm{Ni}_{1 / 3} \mathrm{Ti}_{1 / 3} \mathrm{Al}_{1 / 3}$. Furthermore, the compositional dependences of the calculated lattice parameters $(a, c)$ are presented in Fig. 12 along the line marked by the shaded circles (see inset of Fig. 12) which corresponds to the five compositions (circles 1 to 5), $\mathrm{Ti}_{0.333} \mathrm{Ni}_{0.167} \mathrm{Al}_{0.5}, \quad \mathrm{Ti}_{0.333} \mathrm{Ni}_{0.25} \mathrm{Al}_{0.417}, \quad \mathrm{Ti}_{0.333} \mathrm{Ni}_{0.333} \mathrm{Al}_{0.333}$, $\mathrm{Ti}_{0.417} \mathrm{Ni}_{0.333} \mathrm{Al}_{0.25}$, and $\mathrm{Ti}_{0.5} \mathrm{Ni}_{0.333} \mathrm{Al}_{0.167}$. The trend of the calculated lattice parameters is similar to the experimental data. Calculation and experiments show a minimum at about 35 at\% Al. For three experimental samples the $a$ lattice parameters are larger than our ab-initio data which are attributed to the slightly different compositions of the experimental samples and modeling structures. Furthermore, the measurements were done at $298 \mathrm{~K}$ whereas our calculations refer to $0 \mathrm{~K}$.
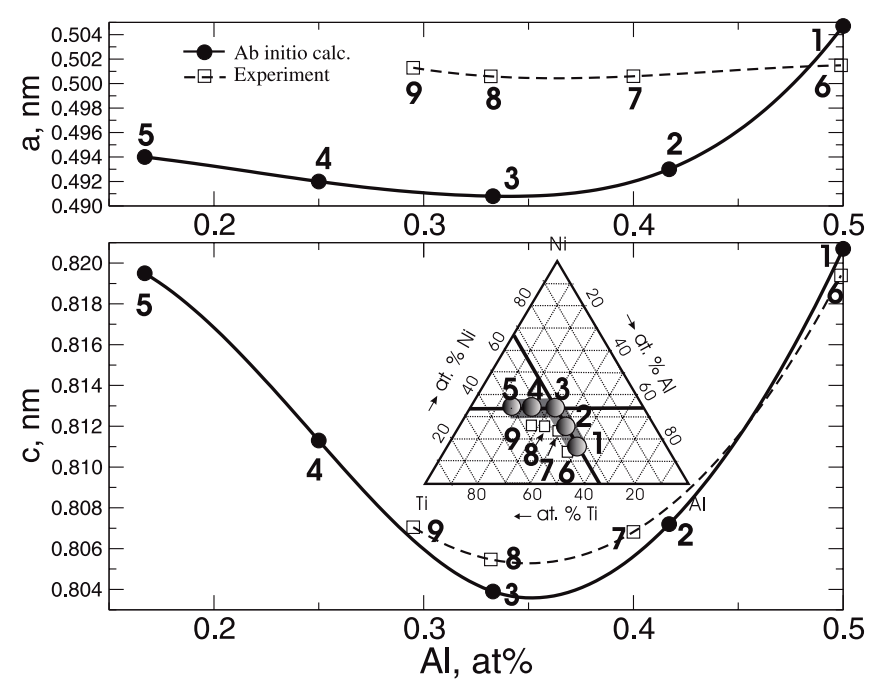

Fig. 12. Compositional dependences of the lattice parameters $a$ and $c$ of the $\mathrm{MgZn}_{2}$-type (C14) structure. The compositions are labeled according to the inserted phase diagram. Labels 1 to 5: model structures; labels 6 to 9: experimental compositions.

Two Ti-rich ternary compounds with fixed 33.3 at $\% \mathrm{Al}$ content, $\left(\mathrm{Ti}_{0.5} \mathrm{Ni}_{0.167} \mathrm{Al}_{0.333}\right.$ and $\mathrm{Ti}_{0.417} \mathrm{Ni}_{0.25} \mathrm{Al}_{0.333}$ shown in Line 3 in Fig. 8), were investigated. The enthalpies of formation and lattice parameters are compiled in Table 8 . For $\mathrm{Ti}_{0.417} \mathrm{Ni}_{0.25} \mathrm{Al}_{0.333}$, the decoration 21 is the most stable one $\left(-48.6 \mathrm{~kJ}\right.$ (mol of atoms) $\left.{ }^{-1}\right)$ for which $\mathrm{Ti}$ and $\mathrm{Ni}$ share $2 a$ sites, whereas the two " $6 h$ " planes are occupied by two $\mathrm{Al}$
Table 8. Models, calculated enthalpies of formation $\left(\Delta H, \mathrm{~kJ}(\mathrm{~mol} \text { of atoms })^{-1}\right)$, and lattice parameter $(\mathrm{nm})$ for site perfectly occupied pseudobinary Laves-phase $\mathrm{Al}_{1 / 3}(\mathrm{Ni}, \mathrm{Ti})_{2 / 3}$ with the $\mathrm{MgZn}_{2}$-type (C14) structure.

\begin{tabular}{|c|c|c|c|c|c|}
\hline Formula & No. & Decorations & $\Delta H$ & $a_{0}$ & $c_{0}$ \\
\hline \multirow[t]{15}{*}{$\mathrm{Ti}_{6 / 12} \mathrm{Ni}_{2 / 12} \mathrm{Al}_{1 / 3}$} & 1 & ${ }^{2 a}\left(\mathrm{Ti}_{2}\right)^{6 h}\left(\mathrm{Al}_{2} \mathrm{Ni}_{1}, \mathrm{Al}_{2} \mathrm{Ni}_{1}\right)^{4 f}\left(\mathrm{Ti}_{4}\right)$ & -41.3 & 0.5124 & 0.8288 \\
\hline & 2 & ${ }^{2 a}\left(\mathrm{Ti}_{2}\right)^{6 h}\left(\mathrm{Al}_{1} \mathrm{Ni}_{2}, \mathrm{Al}_{3}\right)^{4 f}\left(\mathrm{Ti}_{4}\right)$ & -34.8 & 0.5105 & 0.8330 \\
\hline & 3 & ${ }^{2 a}\left(\mathrm{Ti}_{1} \mathrm{Ni}_{1}\right)^{6 h}\left(\mathrm{Ti}_{1} \mathrm{Ni}_{2}, \mathrm{Al}_{3}\right)^{4 f}\left(\mathrm{Ti}_{4}\right)$ & -35.2 & 0.5123 & 0.8141 \\
\hline & 4 & ${ }^{2 a}\left(\mathrm{Ti}_{1} \mathrm{Ni}_{1}\right)^{6 h}\left(\mathrm{Al}_{2} \mathrm{Ti}_{1}, \mathrm{Al}_{2} \mathrm{Ni}_{1}\right)^{4 f}\left(\mathrm{Ti}_{4}\right)$ & -35.9 & 0.5246 & 0.8002 \\
\hline & 5 & ${ }^{2 a}\left(\mathrm{Ti}_{1} \mathrm{Al}_{1}\right)^{6 h}\left(\mathrm{Al}_{3}, \mathrm{Ti}_{1} \mathrm{Ni}_{2}\right)^{4 f}\left(\mathrm{Ti}_{4}\right)$ & -35.0 & 0.5082 & 0.8298 \\
\hline & 6 & ${ }^{2 a}\left(\mathrm{Ti}_{1} \mathrm{Al}_{1}\right)^{6 h}\left(\mathrm{Ni}_{1} \mathrm{Al}_{2}, \mathrm{Ti}_{1} \mathrm{Al}_{1} \mathrm{Ni}_{1}\right)^{4 f}\left(\mathrm{Ti}_{4}\right)$ & -38.1 & 0.4978 & 0.8357 \\
\hline & 7 & ${ }^{2 a}\left(\mathrm{Ti}_{1} \mathrm{Al}_{1}\right)^{6 h}\left(\mathrm{Al}_{1} \mathrm{Ni}_{2}, \mathrm{Ti}_{1} \mathrm{Al}_{2}\right)^{4 f}\left(\mathrm{Ti}_{4}\right)$ & -32.1 & 0.5160 & 0.8194 \\
\hline & 8 & ${ }^{2 a}\left(\mathrm{Ni}_{2}\right)^{6 h}\left(\mathrm{Ti}_{1} \mathrm{Al}_{2}, \mathrm{Ti}_{1} \mathrm{Al}_{2}\right)^{4 f}\left(\mathrm{Ti}_{4}\right)$ & -39.6 & 0.5301 & 0.7686 \\
\hline & 9 & ${ }^{2 a}\left(\mathrm{Ni}_{2}\right)^{6 h}\left(\mathrm{Ti}_{2} \mathrm{Al}_{1}, \mathrm{Al}_{3}\right)^{4 f}\left(\mathrm{Ti}_{4}\right)$ & -36.3 & 0.5237 & 0.7844 \\
\hline & 10 & ${ }^{2 a}\left(\mathrm{Al}_{2}\right)^{6 h}\left(\mathrm{Ti}_{1} \mathrm{Al}_{1} \mathrm{Ni}_{1}, \mathrm{Ti}_{1} \mathrm{Al}_{1} \mathrm{Ni}_{1}\right)^{4 f}\left(\mathrm{Ti}_{4}\right)$ & -36.5 & 0.4968 & 0.8271 \\
\hline & 11 & ${ }^{2 a}\left(\mathrm{Al}_{2}\right)^{6 h}\left(\mathrm{Ti}_{2} \mathrm{Al}_{1}, \mathrm{Al}_{1} \mathrm{Ni}_{2}\right)^{4 f}\left(\mathrm{Ti}_{4}\right)$ & -33.3 & 0.5152 & 0.8227 \\
\hline & 12 & ${ }^{2 a}\left(\mathrm{Al}_{2}\right)^{6 h}\left(\mathrm{Ti}_{1} \mathrm{Al}_{2}, \mathrm{Ti}_{1} \mathrm{Ni}_{2}\right)^{4 f}\left(\mathrm{Ti}_{4}\right)$ & -32.9 & 0.5135 & 0.8250 \\
\hline & 13 & ${ }^{2 a}\left(\mathrm{Ni}_{1} \mathrm{Al}_{1}\right)^{6 h}\left(\mathrm{Ti}_{1} \mathrm{Al}_{2}, \mathrm{Ti}_{1} \mathrm{Al}_{1} \mathrm{Ni}_{1}\right)^{4 f}\left(\mathrm{Ti}_{4}\right)$ & -36.3 & 0.5144 & 0.8006 \\
\hline & 14 & ${ }^{2 a}\left(\mathrm{Ni}_{1} \mathrm{Al}_{1}\right)^{6 h}\left(\mathrm{Ti}_{2} \mathrm{Al}_{1}, \mathrm{Ni}_{1} \mathrm{Al}_{2}\right)^{4 f}\left(\mathrm{Ti}_{4}\right)$ & -34.7 & 0.5145 & 0.8138 \\
\hline & 15 & ${ }^{2 a}\left(\mathrm{Ni}_{1} \mathrm{Al}_{1}\right)^{6 h}\left(\mathrm{Ti}_{2} \mathrm{Ni}_{1}, \mathrm{Al}_{3}\right)^{4 f}\left(\mathrm{Ti}_{4}\right)$ & -34.3 & 0.5067 & 0.8190 \\
\hline \multirow[t]{11}{*}{$\mathrm{Ti}_{5 / 12} \mathrm{Ni}_{3 / 12} \mathrm{Al}_{1 / 3}$} & 16 & ${ }^{2 a}\left(\mathrm{Ti}_{1} \mathrm{Ni}_{1}\right)^{6 h}\left(\mathrm{Ni}_{2} \mathrm{Al}_{1}, \mathrm{Al}_{3}\right)^{4 f}\left(\mathrm{Ti}_{4}\right)$ & -39.3 & 0.5024 & 0.8088 \\
\hline & 17 & ${ }^{2 a}\left(\mathrm{Ti}_{1} \mathrm{Ni}_{1}\right)^{6 h}\left(\mathrm{Ni}_{1} \mathrm{Al}_{2}, \mathrm{Ni}_{1} \mathrm{Al}_{2}\right)^{4 f}\left(\mathrm{Ti}_{4}\right)$ & -44.7 & 0.4916 & 0.8173 \\
\hline & 18 & ${ }^{2 a}\left(\mathrm{Ni}_{2}\right)^{6 h}\left(\mathrm{Al}_{1} \mathrm{Ti}_{1} \mathrm{Ni}_{1}, \mathrm{Al}_{3}\right)^{4 f}\left(\mathrm{Ti}_{4}\right)$ & -43.7 & 0.5034 & 0.7868 \\
\hline & 19 & ${ }^{2 a}\left(\mathrm{Ni}_{2}\right)^{6 h}\left(\mathrm{Al}_{2} \mathrm{Ni}_{1}, \mathrm{Al}_{2} \mathrm{Ni}_{1}\right)^{4 f}\left(\mathrm{Ti}_{4}\right)$ & -43.8 & 0.5072 & 0.7771 \\
\hline & 20 & ${ }^{2 a}\left(\mathrm{Ti}_{1} \mathrm{Al}_{1}\right)^{6 h}\left(\mathrm{Al}_{3}, \mathrm{Ni}_{3}\right)^{4 f}\left(\mathrm{Ti}_{4}\right)$ & -37.2 & 0.5036 & 0.8086 \\
\hline & 21 & ${ }^{2 a}\left(\mathrm{Ti}_{1} \mathrm{Al}_{1}\right)^{6 h}\left(\mathrm{Al}_{2} \mathrm{Ni}_{1}, \mathrm{Al}_{1} \mathrm{Ni}_{2}\right)^{4 f}\left(\mathrm{Ti}_{4}\right)$ & -48.6 & 0.5041 & 0.8178 \\
\hline & 22 & ${ }^{2 a}\left(\mathrm{Al}_{2}\right)^{6 h}\left(\mathrm{Ti}_{1} \mathrm{Ni}_{2}, \mathrm{Al}_{2} \mathrm{Ni}_{1}\right)^{4 f}\left(\mathrm{Ti}_{4}\right)$ & -46.6 & 0.4924 & 0.8232 \\
\hline & 23 & ${ }^{2 a}\left(\mathrm{Al}_{2}\right)^{6 h}\left(\mathrm{Ti}_{1} \mathrm{Al}_{1} \mathrm{Ni}_{1}, \mathrm{Al}_{1} \mathrm{Ni}_{2}\right)^{4 f}\left(\mathrm{Ti}_{4}\right)$ & -43.4 & 0.4942 & 0.8099 \\
\hline & 24 & ${ }^{2 a}\left(\mathrm{Al}_{2}\right)^{6 h}\left(\mathrm{Al}_{2} \mathrm{Ti}_{1}, \mathrm{Ni}_{3}\right)^{4 f}\left(\mathrm{Ti}_{4}\right)$ & -36.9 & 0.5129 & 0.7915 \\
\hline & 25 & ${ }^{2 a}\left(\mathrm{Al}_{1} \mathrm{Ni}_{1}\right)^{6 h}\left(\mathrm{Al}_{2} \mathrm{Ti}_{1}, \mathrm{Al}_{1} \mathrm{Ni}_{2}\right)^{4 f}\left(\mathrm{Ti}_{4}\right)$ & -38.9 & 0.5114 & 0.7912 \\
\hline & 26 & ${ }^{2 a}\left(\mathrm{Al}_{1} \mathrm{Ni}_{1}\right)^{6 h}\left(\mathrm{Ni}_{2} \mathrm{Ti}_{1}, \mathrm{Al}_{3}\right)^{4 f}\left(\mathrm{Ti}_{4}\right)$ & -39.7 & 0.5026 & 0.8066 \\
\hline
\end{tabular}

a: Bold numbers denote most stable decorations 

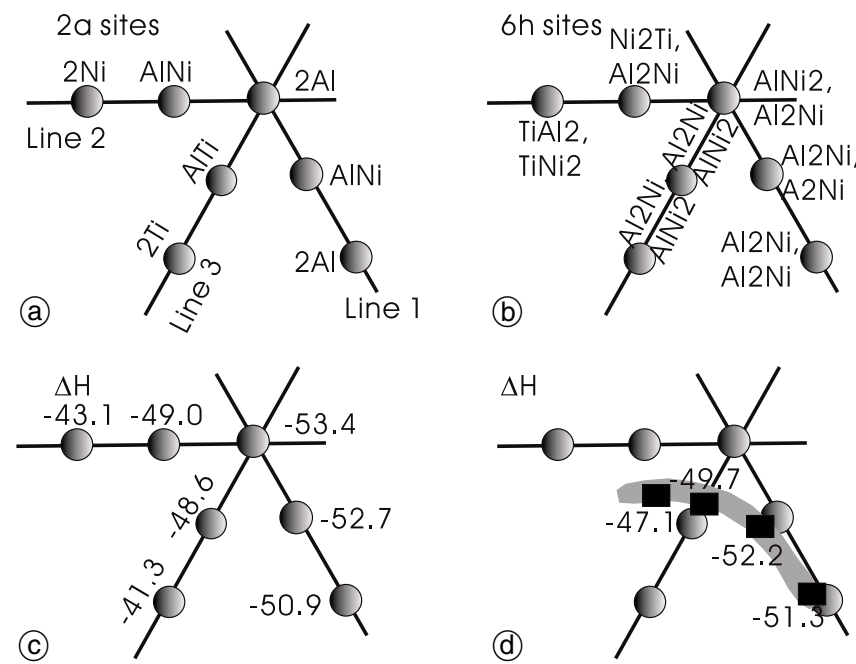

Fig. 13. Atomic distributions and enthalpies of formation (kJ (mol of atoms $)^{-1}$ ) for the most stable decorations for the calculated samples along Line 1, Line 2, and Line 3 of Fig. 8. Panels (a) and (b) denote atomic occupation of $2 a$ and $6 h$ sites; panel (c) the calculated enthalpies of formation; (d) averaged values for the experimental compositions.

and one $\mathrm{Ni}$, and one $\mathrm{Al}$ and two $\mathrm{Ni}$, respectively. With increasing Ti content up to 50 at $\%$ the most stable decoration is number one, ${ }^{2 a}\left(\mathrm{Ti}_{2}\right)^{6 h}\left(\mathrm{Al}_{2} \mathrm{Ni}_{1}, \mathrm{Al}_{2} \mathrm{Ni}_{1}\right)^{4 f}\left(\mathrm{Ti}_{4}\right)$, with a formation enthalpy of $-41.3 \mathrm{~kJ}$ (mol of atoms) ${ }^{-1}$. Now, the $2 a$ and $4 f$ sites are fully occupied by Ti, and each of the " $6 h$ " planes has two $\mathrm{Al}$ and one Ni. Thus, with decreasing Ti concentrations $\quad\left(\mathrm{Al}_{0.333} \mathrm{Ti}_{0.5} \mathrm{Ni}_{0.167}, \quad \mathrm{Al}_{0.333} \mathrm{Ti}_{0.417} \mathrm{Ni}_{0.25}\right.$, $\left.\mathrm{Al}_{0.333} \mathrm{Ti}_{0.333} \mathrm{Ni}_{0.333}\right)$ the $2 a$ sites are firstly occupied by $\mathrm{Ti}$ (decoration 1 in Table 8), and then are shared by Ti and Al (decoration 21 in Table 8), finally are completely filled by $\mathrm{Al}$ atoms (decoration 11 in Table 5).

By neutron diffraction the atomic distribution for the two compounds $\mathrm{Ti}_{0.40} \mathrm{Ni}_{0.27} \mathrm{Al}_{0.33}$ and $\mathrm{Ti}_{0.44} \mathrm{Ni}_{0.27} \mathrm{Al}_{0.29}$ was determined (see Table $2 \mathrm{~b}$ ): $2 a$ and $6 h$ sites are shared by all three types of atoms Al, Ni, and Ti. This situation is not modeled by our suprecells. However, by a weighted average of enthalpies of formation according to Fig. 13, enthalpies of formation for the experimental compositions are derived. For calculating the enthalpy of formation of the experimental compositions $\left(\mathrm{Ti}_{0.40} \mathrm{Ni}_{0.27} \mathrm{Al}_{0.33}\right.$ and $\left.\mathrm{Ti}_{0.44} \mathrm{Ni}_{0.27} \mathrm{Al}_{0.29}\right)$ for $\mathrm{Ti}_{0.44} \mathrm{Ni}_{0.27} \mathrm{Al}_{0.29}$ three compositions $\left(\mathrm{Ti}_{0.333} \mathrm{Ni}_{0.333} \mathrm{Al}_{0.333}\right.$, $\mathrm{Ti}_{0.417} \mathrm{Ni}_{0.333} \mathrm{Al}_{0.25}$, and $\mathrm{Ti}_{0.417} \mathrm{Ni}_{0.25} \mathrm{Al}_{0.333}$ ) were modeled whereas for $\mathrm{Ti}_{0.5} \mathrm{Ni}_{0.167} \mathrm{Al}_{0.333}$ four compositions $\left(\mathrm{Ti}_{0.417} \mathrm{Ni}_{0.333} \mathrm{Al}_{0.25}, \quad \mathrm{Ti}_{0.417} \mathrm{Ni}_{0.25} \mathrm{Al}_{0.333}, \quad \mathrm{Ti}_{0.5} \mathrm{Ni}_{0.333} \mathrm{Al}_{0.167}\right.$, and $\mathrm{Ti}_{0.5} \mathrm{Ni}_{0.167} \mathrm{Al}_{0.333}$ ) were accounted. In the same way an averaged site occupation can be derived in close agreement with the experimental finding that all three types of atoms $\mathrm{Ti}, \mathrm{Al}$, and $\mathrm{Ni}$ sharing the $2 a$ and $6 h$ sites (see Fig. $13(a)$ and $(b))$. The averaged enthalpies of formation of -49.7 for $\mathrm{Ti}_{0.40} \mathrm{Ni}_{0.27} \mathrm{Al}_{0.33}$ and $-47.1 \mathrm{~kJ}$ (mol of atoms) ${ }^{-1}$ for $\mathrm{Ti}_{0.44} \mathrm{Ni}_{0.27} \mathrm{Al}_{0.29}$ are crosschecked by four $96-$ atom supercell calculations as described in section "models and ab-initio calculations". For $\mathrm{Ti}_{0.40} \mathrm{Ni}_{0.27} \mathrm{Al}_{0.33}$ the model structure C.1 is more stable by $2 \mathrm{~kJ}$ (mol of atoms) $)^{-1}$ than C. 2 which is very similar to $\mathrm{Ti}_{0.44} \mathrm{Ni}_{0.27} \mathrm{Al}_{0.29}$, for which D.1 is more stable by $2 \mathrm{~kJ}$ (mol of atoms) $)^{-1}$ than D.2. The $2 a$ sites of the C. 1 and D. 1 structures are shared by all three types of atoms $\mathrm{Ti}, \mathrm{Al}$ and $\mathrm{Ni}$ in full agreement with ex-

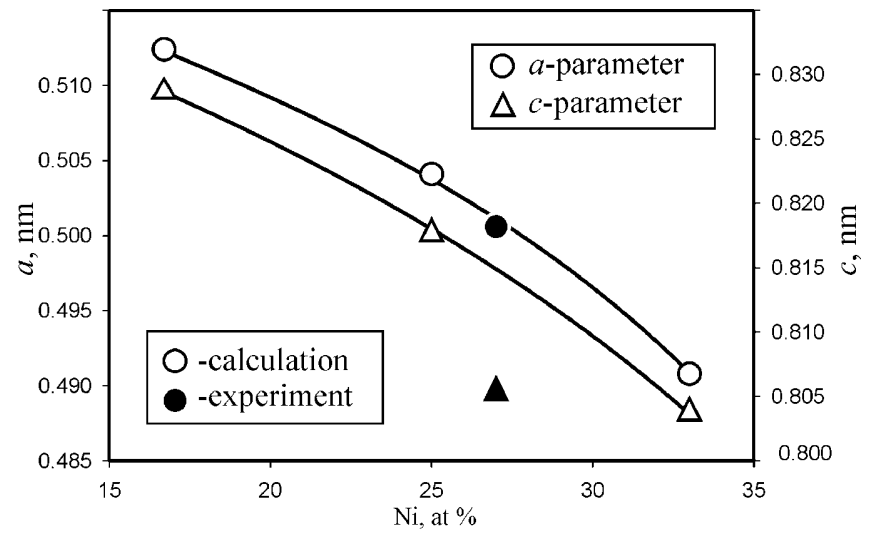

Fig. 14. Lattice parameters of $\mathrm{Ti}_{0.5} \mathrm{Ni}_{0.167} \mathrm{Al}_{0.333}, \mathrm{Ti}_{0.417} \mathrm{Ni}_{0.25} \mathrm{Al}_{0.333}$ and $\mathrm{Ti}_{0.333} \mathrm{Ni}_{0.333} \mathrm{Al}_{0.333}(33.3$ at $\% \mathrm{Al})$.

periment. Mainly because of structural relaxation, the enthalpies of formation derived by the averaging procedure are always lower in energy as compared to the 96-atom supercell calculation with their fixed experimental lattice parameters as given in Table 6. At present, for the two experimental compositions no measured enthalpies of formation are available.

The dependence of the calculated lattice parameters at fixed 33.3 at\% $\mathrm{Al}$ (decorations 1 and 21 from Table 8, and decoration 11 from Table 5) are in good agreement with the experimental data for $\mathrm{Ti}_{0.40} \mathrm{Ni}_{0.27} \mathrm{Al}_{0.33}$ (see Fig. 14). Because the Al content is fixed the lattice parameters vary according to the atomic volumes of $\mathrm{Ni}$ and Ti: for increasing $\mathrm{Ti}$ and decreasing Ni content the parameters $a$ and $c$ increase, and vice versa.

The volume dependent enthalpies of formation for the compounds $\mathrm{Ti}_{0.333} \mathrm{Al}_{0.333} \mathrm{Ni}_{0.333}, \quad \mathrm{Ti}_{0.333} \mathrm{Al}_{0.417} \mathrm{Ni}_{0.25}$, and $\mathrm{Ti}_{0.333} \mathrm{Al}_{0.5} \mathrm{Ni}_{0.167}$ are compiled in Fig. 15 from which we derived the bulk moduli of $146.4,135.7$, and 145.7 GPa, respectively. In comparison, for the compound $\mathrm{Ti}_{0.417} \mathrm{Al}_{0.333} \mathrm{Ni}_{0.25}$ the calculated bulk modulus is $142.3 \mathrm{GPa}$. Its lattice parameters $a=5.041 \AA$ and $c=8.178 \AA$ agree within $2 \%$ with respect to the neutron experiments on $\mathrm{Ti}_{0.40} \mathrm{Ni}_{0.27} \mathrm{Al}_{0.33}$ as shown in Table $2 \mathrm{~b}$.

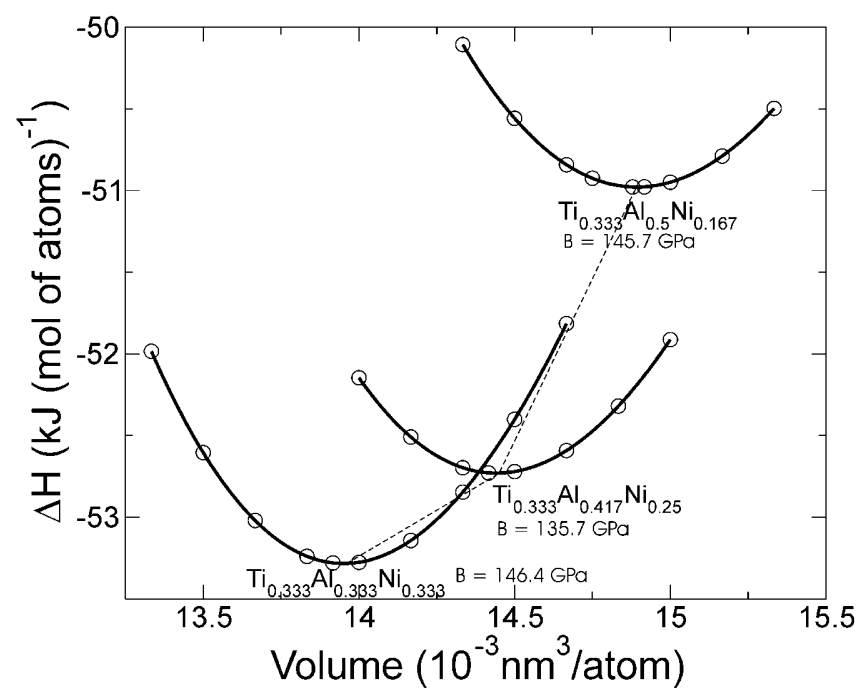

Fig. 15. Enthalpies of formation versus volume and bulk moduli for $\mathrm{Ti}_{0.333} \mathrm{Al}_{0.333} \mathrm{Ni}_{0.333}, \mathrm{Ti}_{0.333} \mathrm{Al}_{0.417} \mathrm{Ni}_{0.25}$, and $\mathrm{Ti}_{0.333} \mathrm{Al}_{0.5} \mathrm{Ni}_{0.167}$. 


\section{Conclusion}

This investigation combines experimental techniques and $a b$-initio calculations to elucidate the structural and thermodynamic properties for the truly ternary Laves phase $\operatorname{Ti}\left(\mathrm{Ti}_{y} \mathrm{Ni}_{x} \mathrm{Al}_{1-x-y}\right)_{2}$ of $\mathrm{MgZn}_{2}$-type. The Ti-rich end of the homogeneity region of the Laves phase at $1000{ }^{\circ} \mathrm{C}$ was evaluated from EMPA to be at $\mathrm{Ti}_{0.463} \mathrm{Ni}_{0.273} \mathrm{Al}_{0.264}$ confirming the "boomerang"-shaped phase region changing from constant Ti-content (33.3 at\%) to constant Ni-content (27 at\% Ni). Refinement of neutron powder, X-ray single crystal and powder diffraction data defined the precise atom occupation and site preference: Ti atoms fully occupy the $4 f$ site, whilst Niand Al-atoms randomly share the $2 a$ and $6 h$ sub-lattice sites of space group $P 6_{3} / m m c$. At Ti-concentrations higher than 33.3 at $\%$, Ti-atoms enter the $2 a$ and $6 h$ site. The compositional dependences of the site occupations explain the curved shape of the homogeneity region and are reflected in the variation of the unit cell dimensions with concentration. Heat of formation data from adiabatic drop calorimetry were $\Delta_{298} H^{0}=-57.9 \pm 3.5 \mathrm{~kJ} / \mathrm{mol}$ for $\mathrm{Ti}_{0.34} \mathrm{Ni}_{0.18} \mathrm{Al}_{0.48}$ and $-61.6 \pm 3.3 \mathrm{~kJ} / \mathrm{mol}$ for $\mathrm{Ti}_{0.36} \mathrm{Ni}_{0.24} \mathrm{Al}_{0.40}$. For the ab-initio density functional theory calculations a large number of models were investigated in order to simulate the ternary Laves compounds with the experimental compositions. The calculated concentration dependent heats of formation, structural stabilities, lattice parameters and site occupancies are in good agreement with the experimental findings.

Acknowledgments. This work was supported by the Austrian Science Fund FWF project no. P16957 and P16778. A.S. and P.R. are both grateful to the Austrian - Italian Scientific - Technological Exchange Program in support of project 16/2004 for fellowships in Genova and Wien, respectively. This work was partially performed at the spallation neutron source SINQ, Paul Scherrer Institute, Villigen, Switzerland.

\section{References}

[1] Huneau, B.; Rogl, P.; Zheng, K.; Schmid-Fetzer, R.; Bohn, M.; Bauer, J.: The ternary system $\mathrm{Al}-\mathrm{Ni}-\mathrm{Ti}$. I. Isothermal section at 900 degrees $\mathrm{C}$, experimental investigation and thermodynamic calculation. Intermetallics 7 (1999) 1337-1345.

[2] Zeng, K.; Schmid-Fetzer, R.; Huneau, B.; Rogl, P.; Bauer, J.: The ternary system Al-Ni-Ti. II. Thermodynamic assessment and experimental investigation of polythermal phase equilibria. Intermetallics 7 (1999) 1347-1359.

[3] Ding, J. J.; Rogl, P.; Schmidt, H.: Phase relations in the Al-rich corner of the $\mathrm{Ti}-\mathrm{Ni}-\mathrm{Al}$ system. J. Alloys Compounds 317318 (2001) 379-384.

[4] Nonius Kappa CCD Program Package COLLECT, DENZO, SCALEPACK, SORTAV. Nonius Delft, The Netherlands, 1998.

[5] Sheldrick, G. M: SHELXL-97, Program for Crystal Structure Refinement. University of Göttingen, Germany. Windows version by McArdle, Natl. Univ. Ireland, Galway, 1997.

[6] Fischer, P.; Frey, G.; Koch, M.; Koennecke, M.; Pomjakushin, V.; Schefer, J.; Thut, R.; Schlumpf, N.; Buerge, R.; Greuter, U.; Bondt, S; Berruyer E.: High-resolution powder diffractometer HRPT for thermal neutrons at SINQ. Physica B276-278 (2000) 146-147.

[7] Roisnel, T.; Rodriguez-Carvajal, J.: WinPLOTR: a Windows tool for powder diffraction pattern analysis. Materials-Science-Forum 378-381 (2001) 118-123.

[8] INCA Energy-300, Oxford Instruments Analytical Ltd., UK 2000.

[9] Chen, X. Q.; Witusiewicz, V. T.; Podloucky, R.; Rogl, P.; Sommer, F.: Computational and experimental study of phase stabi- lity, cohesive properties, magnetism and electronic structure of $\mathrm{TiMn}_{2}$. Acta Mater. 51 (2003) 1239-1247.

[10] Dinsdale, A. T.: SGTE data for pure elements. CALPHAD 15 (1991) 317-425.

[11] Kresse, G. and Furthmüller, J.: Efficiency of ab initio total energy calculation for metals and semiconductors using a planewave set. Comput. Mater. Sci. 6 (1996) 15-50; Efficient iterative schemes for $a b$ initio total-energy calculations using a plane-wave basis set. Phys. Rev. B54 (1996) 11169-11186.

[12] Kresse, G.; Joubert, D.: From ultrasoft pseudopotentials to the projector augmented-wave method. Phys. Rev. B59 (1999) $1758-1775$.

[13] Perdew, J. P. and Wang, Y.: Accurate and simple analytic representation of the electron-gas correlation energy, Phys. Rev. B45 (1992) 13244-13249.

[14] Monkhorst, H. J.; Pack, J. D.: Special points for Brillouin-zone integrations. Phys. Rev. B13 (1976) 5188-5192.

[15] Geld, P. V.; Esin, Yu. O.; Petrushevski, M. S.: Proc. of Fifth Conference on Calorimetry. (in Russian), Moscow Uni., Moscow (1971) 42.

[16] Pool, H. L.; Starr, J.; Griffith, W. W.: Proc. of Symposium of Thermodynamics of Alloys. Munster (1972).

[17] Dannöhl, H.-D.; Lukas, H. L.: Calorimetric determination of the enthalpies of formation of some intermetallic compounds. Z. Metallkd. 65 (1974) 642-649.

[18] Henig, E. Th.; Lukas, H. L.: Calorimetric determination of the enthalpies of formation and description of the defect structure of the ordered $\beta$-phase $(\mathrm{Ni}, \mathrm{Cu})_{1-x} \mathrm{Al}_{x}$. Z. Metallkd. 66 (1975) 98.

[19] Diaz, H.; Percheron-Guegan, A.; Archard, J. C.; Chattilon-Colinet, C.; Mathieu, J. C.: Proc. Second Word Hydrogen Energy Conference. Zurich (1978).

[20] Jeymound, M.; Landaud, D.; Legardeur, M.; Pasturel, A.: Microcomputer controlled experimentation in carlorimetry. Application to the determination of the partial enthalpies of $3 d$ transition metals in liquid aluminium. Thermochim. Acta 55 (1982) 301306.

[21] Henaff, M. P.; Colinet, C. C.; Pasturel, A.; Buschow, K. H. J.: Study of the enthalpies of formation and crystallization in the system Zr-Ni. J. Appl. Phys. 56 (1984) 307-310.

[22] Lee, J.-J.; Sommer, F.: The determination of the partial enthalpies of mixing of aluminium-rich alloy melts by solution calorimetry. Z. Metallkd. 76 (1985) 750-754.

[23] Gomozov, P. A.; Zasypalov, Yu. V.; Mogutnov, B. M: Enthalpies of formation of intermetal compounds with the $\mathrm{CsCl}$ (CoTi, CoZr, CoAl, NiTi) structure. J. Phys. Chem. (in Russian) 60 (1986) 1865-1867.

[24] Zasypalov, Yu. V.; Kiselev, O. A.; Mogutnov, B. M.: Enthalpies of formation of intermetallic compounds $\mathrm{CoTi}_{1-x} \mathrm{Al}_{x}$ and $\mathrm{TiNi}_{1-x} \mathrm{Co}_{x}(0<x<1)$. Dokl. Acad. Nauk USSR (in Russian), 287 (1986) $158-161$.

[25] Zubkov, A. A.: Dissolution enthalpies of 3d transition metals in liquid aluminium. J. Chem. Thermodyn. 26 (1994) 1267-1274.

[26] Turchanin, A. A.; Tomilin, I. A.; Zubkov, A. A.: Experimental determination of the formation enthalpies of nickel-zirconium and nickel-zirconium-titanium amorphous alloys. Mater. Sci. Forum 235-238 (1997) 367-372.

[27] Esin, Yu. O.; Bobrov, N. P.; Petrushevski, M. S.; Geld P. V.: Enthalpy of the formation of liquid alloys of $\mathrm{Al}$ with $\mathrm{Ti}$ and $\mathrm{Zr}$. Izv. AN SSSR. Metally (in Russian) 5 (1974) 104-109.

[28] Witusiewicz, V. T.; Arpshofen, I.; Seifert, H.-J.; Sommer, F.; Aldinger, F.: Thermodynamics of liquid and undercooled liquid Al-Ni-Si alloys. J. Alloys Comp. 305 (2000) 157-171

[29] Batalin, G. I.; Beloborodova, E. A.; Nerubaschenko, V. V.; Shlapak, A. N.: Heats os solution of titanium, zirconium and boron in liquid aluminium Russian Metallurgy 1 (1981) 61-63. (in Russian)

[30] Esin, Yu. O.; Bobrov, N. P.; Petrushevski, M. S.; Geld, P. V.: Concentration-dependence of enthalpies of formation of $\mathrm{Mn}$, Al-melts at 1626 K. J. Phys. Chem. (in Russian) 47 (1973) 1959-1962.

[31] Stolz, U. K.; Arpshofen, I.; Sommer, F.; Predel, B.: Determination of the enthalpy of mixing of liquid alloys using a hightemperature mixing calorimeter. J. Phase Equ. 14 (1993) 473478 . 
[32] Gizenko, N. V.; Kilesko, S. N.; Ilnikov, D. V.; Einlin, B. J.; Zavylov, A. L.: Izv. V.U.Z. Tsvetn. Metall. (in Russian) 4 (1982) 21.

[33] Sudavtsova, V. S.; Shuvalov, A. V.; Sharkina, N. O.: Rasplavy (in Russian) 4 (1990) 97.

[34] Witusiewicz, V. T.; Sommer, F.: Thermodynamics of liquid $\mathrm{Al}-\mathrm{Ni}-\mathrm{Zr}$ and $\mathrm{Al}-\mathrm{Cu}-\mathrm{Ni}-\mathrm{Zr}$ alloys. J. Alloys Comp. 286 (1999) 152-167.

[35] Yassin, A.; Castanet, R.: Enthalpies of dissolution of elements in liquid tin. II. Transition, alkali and alkaline-earth metals. J. Alloys Comp. 314 (2001) 160-166.

[36] Yassin, A.; Castanet, R.: Enthalpies of dissolution of elements in liquid tin: a review III. elements of columns IIB, IIIA, IVA, VA and VIE of the periodic table. J. Alloys Comp. 320 (2001) 8086.

[37] Chiotti, P.; Ackachinskij, V. V.; Ansara, I.; Rand, M. H.: The Chemical Thermodynamics of Actinide Elements. Part 5 The Actinide Binary Alloys (Ed. Medvedev V.), p. 84. IAEA, Vienna (1981).

[38] Kassner, M. E.; Adler, P. H.; Adamson, M. G.; Peterson, D. E.: Evaluation and thermodynamic analysis of phase equilibria in the U-Al system. J. Nucl. Mater. 167 (1989) 160-168.

[39] Rzyman, K.; Moser, Z.; Watson, R. E.; Weinert, M.: Enthalpies of formation of AlNi: experiment versus theory. J. Phase Equ. 19 (1998) 106-111.

[40] Parthé, E.; Gelato, L.; Chabot, B.; Penzo, M.; Cenzual, K.; Gladyshevskii, R.: TYPIX Standardized Data and Crystal Chemical Characterization of Inorganic Structure Types. Springer - Verlag, Berlin, Heidelberg, 1994.

[41] Jung, J.; Ghosh, G.; Olson, G. B.: A comparative study of precipitation behavior of Heusler phase $\left(\mathrm{Ni}_{2} \mathrm{TiAl}\right)$ from $\mathrm{B}_{2}$-TiNi in $\mathrm{Ni}-\mathrm{Ti}-\mathrm{Al}$ and $\mathrm{Ni}-\mathrm{Ti}-\mathrm{Al}-\mathrm{X}(\mathrm{X}=\mathrm{Hf}, \mathrm{Pd}, \mathrm{Pt}, \mathrm{Zr})$ alloys. Acta Mater. 51 (2003) 6341-6357.

[42] Ghosh, G.; Asta, M.: First-principles calculation of structural energetics of $\mathrm{Al}-\mathrm{TM}(\mathrm{TM}=\mathrm{Ti}, \mathrm{Zr}, \mathrm{Hf})$, Acta Mater. 53 (2005) $3225-3252$

[43] Asta, M.; de Fontaine, D.; Van Schilfgaarde, M.; Sluiter, M.; Methfessel M.: First-principles phase-stability study of fcc alloys in the Ti-Al systems. Phys. Rev. B46 (1992) 5055-5072.

[44] Asta, M.; de Fontaine, D.; Van Schilfgaarde, M.: First-principles study of phase stability of $\mathrm{Ti}-\mathrm{Al}$ intermetallic compounds. J. Mater Res. 8 (1993) 2554-2568.

[45] Watson, R. E.; Weinert, M.: Transition-metal aluminide formation: Ti, V, Fe and Ni aluminides. Phys. Rev. B58 (1998) 59815988.

[46] Nguyen-Mahn, D.; Pettifor, D. G.: Electronic structure, phase stability and elastic moduli of $\mathrm{AB}$ transition metal aluminides. Intermetallics 7 (1999) 1095-1106.

[47] Zou, J.; Fu, C. L.; Yoo, M. H.: Phase stability of intermetallics in the Al-Ti system: A first-principles total-energy investigation. Intermetallics 3 (1995) 265-269.
[48] Zou, J.; Fu, C. L.: Structural, electronic, and magnetic properties of $3 d$ transition-metal aluminides with equiatomic composition. Phys. Rev. B51 (1995) 2115-2121.

[49] Kubaschewski, O.: Thermodynamical properties of titanium, its compounds and alloys. Atomic Energy Review 9 (1983) $3-71$.

[50] Nassik, M.; Chrifi-Alaoui, F. Z.; Mahdouk, K.; Gachon, J. C.: Calorimetric study of the aluminium-titanium system. J. Alloy Compd. 350 (2003) 151-154.

[51] Kaufman, L.; Nesor, H.: Coupled phase diagrams and thermodynamical data for transition metal binary systems-V. CALPHAD 2 (1978) 325-348.

[52] Zhang, F.; Chen, S. L.; Chang, Y. A.; Kattner, U. R.: A thermodynamic description of the $\mathrm{Ti}-\mathrm{Al}$ system. Intermetallics $\mathbf{5}$ (1997) 471-482.

[53] Ohnuma, I.; Fujita, Y.; Mitsui, H.; Ishikawa, K.; Kainuma, R.; Ishida, K.: Phase equilibria in the Ti-Al binary system. Acta Mater. 48 (2000) 3113-3123.

[54] Fu, C. L.: Electronic, elastic, and fracture properties of trialuminides alloys: $\mathrm{Al}_{3} \mathrm{Sc}$ and $\mathrm{Al}_{3} \mathrm{Ti}$. J. Mater. Res. 5 (1990) 971-979.

[55] Hong, T.; Watson-Yang, T. J.; Freeman, A. J.; Oguchi, T.; Xu, J. H.: Crystal structure, phase stability, and electronic structure of Ti-Al intermetallics: $\mathrm{TiAl}_{3}$. Phys. Rev. B41 (1990) $12462-$ 12467.

[56] Hong, T.; Freeman, A. J.: Effect of ternary additions on the structural stability and electronic structure of intermetallic compounds $\mathrm{Al}_{3} \mathrm{Ti}+\mathrm{Cu}$. J. Mater. Res. 6 (1991) 330-338.

[57] Xu, J. H.; Freeman, A. J.: Bandfilling and structural stability of trialuminides, $\mathrm{YAl}_{3}, \mathrm{ZrAl}_{3}$, and $\mathrm{NbAl}_{3}$, J. Mater Res. 6 (1991) $1188-1199$.

[58] Colinet, C.; Pasturel, A.: Ab initio calculation of the formation energies of $\mathrm{L}_{12}, \mathrm{DO}_{22}, \mathrm{DO}_{23}$ and one dimensional long period structures in $\mathrm{TiAl}_{3}$ compound. Intermetallics 10 (1002) 751-764.

[59] Pasturel, A.; Colinet, C.; Nguyen Manh, D.; Paxton, A. T.; Van Schilfgaarde, M.: Electronic structure and phase stability study in the Ni-Ti system. Phys. Rev. B52 (1995) 15176-15190.

[60] Guo, Q.; Kleppa, O. J.: Standard enthalpies of formation of some alloys formed between group IV elements and group VIII elements, determined by high-temperature direct synthesis calorimetry: II. Alloys of ( $\mathrm{Ti}, \mathrm{Zr}$, Hf) with (Co, Ni). J. Alloys Comp. 269 (1998) 181-186.

[61] Chen, X. Q.; Wolf, W.; Podloucky, R.; Rogl, P.: Density functional study of structural and phase stabilities for $\mathrm{RMn}_{2}$ Laves phases ( $\mathrm{R}=\mathrm{Sc}, \mathrm{Y}, \mathrm{Lu}, \mathrm{Ti}, \mathrm{Zr}, \mathrm{Hf})$. J. Alloys Comp. 383 (2004) $228-331$

[62] Chen, X. Q.; Wolf, W.; Podloucky, R.; Rogl, P.: Comment on enthalpies of formation of binary Laves phases. Intermetallics $\mathbf{1 2}$ (2004) 59-62.

[63] Chen, X. Q.; Wolf, W.; Podloucky, R.; Rogl, P.: Ab initio study of ground-state properties of the Laves phase compounds $\mathrm{TiCr}_{2}$, $\mathrm{ZrCr}_{2}$, and $\mathrm{HfCr}_{2}$. Phys. Rev. B71 (2005) 174101-174111. 